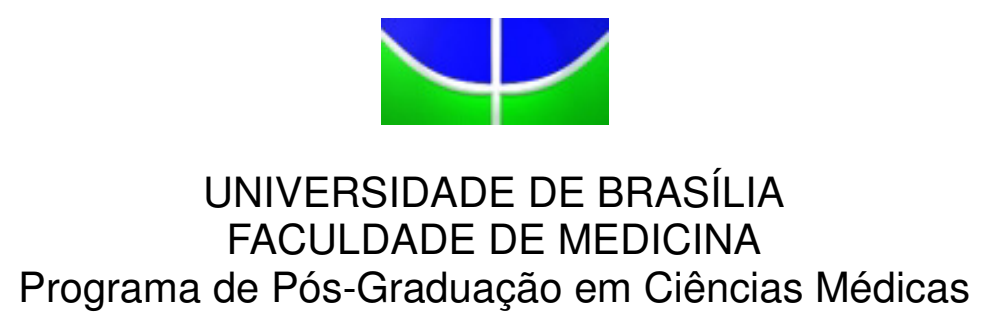

INFLUÊNCIA DA MUSICOTERAPIA NO COMPORTAMENTO DE ANIMAIS EM DESENVOLVIMENTO

WANELI CRISTINE MORAIS SAMPAIO

BRASÍLIA-DF 2015 


\section{INFLUÊNCIA DA MUSICOTERAPIA NO COMPORTAMENTO DE ANIMAIS EM DESENVOLVIMENTO}

Dissertação de Mestrado apresentada ao Programa de Pós-Graduação em Ciências Médicas, da Faculdade de Medicina, da Universidade de Brasília, como requisito para a obtenção do título de Mestre em Ciências Aplicadas á Saúde.

Orientadora: Profa. Dra. Vania Maria Moraes Ferreira 


\section{INFLUÊNCIA DA MUSICOTERAPIA NO COMPORTAMENTO DE ANIMAIS EM DESENVOLVIMENTO}

Dissertação de Mestrado apresentada ao Programa de PósGraduação em Ciências Médicas, Faculdade de Medicina, Universidade de Brasília, como requisito para a obtenção do título de Mestre em Ciências Aplicadas em Saúde.

Aprovada em 29 de Maio de 2015

BANCA EXAMINADORA

Profa. Dra. Vania Moraes Ferreira

(Presidente)

Universidade de Brasília

$\overline{\text { Profa. Dra. Maria Ângela Guimarães Feitosa }}$

(Membro Titular)

Universidade de Brasília

\section{Prof. Dr. Luciano Grudtner Buratto \\ (Membro Titular) \\ Universidade de Brasília}

Profa Dra. Goiara Mendonça de Castilho

(Membro Suplente)

Universidade de Brasília 
Dedico esta Dissertação de Mestrado aos mens pais por terem inserido em minha formação, como individuo, valores nobres como sensibitidade, caráter, respeito e perseverança. Ao men esposo, por ter se doado de diversas formas para que este sonho fosse realizado. Ao meu fitho Arthur por me fazer buscar, diariamente $\sigma$ melhor de mim e ser minha fonte de alegria, de amor e sabedoría. 


\section{AGRADECIMENTOS}

- A Deus, que me capacita, cuida e me ama incondicionalmente, transformando minha mente e meu coração, para ajudar o maior número de pessoas nesta atual existência.

* Á minha Orientadora, Profa. Dra Vânia Ferreira, pela competência e por sua orientação, bem como pela oportunidade de aprimorar meus conhecimentos por meio do universo da pesquisa.

* Ao Programa de Pós-Graduação em Ciências Médicas e ao seu corpo docente, por todo conhecimento compartilhado.

- A minha querida e admirável companheira de profissão da Musicoterapia e Pianista Moema Craveiro Campos pela ajuda, por sua disponibilidade e sensibilidade.

* À equipe do Laboratório de Patologia, da Faculdade de Medicina, por incentivar novas pesquisas e contribuir para a viabilização deste trabalho.

- Ao Biotério da Faculdade Sena Aires (Valparaíso de Goiás-GO), pelo fornecimento de animais experimentais.

- Ao Sr. Dedé, técnico da Faculdade de Saúde, da Universidade de Brasília, pelos cuidados diários com os animais experimentais de uma maneira extremamente responsável.

* Aos colegas que faziam ou ainda fazem parte do nosso grupo de estudo, como João Eudes, Aluízio, Melissa e, atualmente, a Mara por todas as trocas, que contribuíram junto com as intervenções de minha orientadora para meu enorme crescimento.

- Ao meu amigo Hugo por ter me apresentado a minha orientadora e, desta forma, possibilitar a conclusão deste Mestrado. 
"Plante um pensamento, cotha uma ação; plante uma ação, colha um hábito; plante um hábito, colha um caráter; plante un caráter, cotha um destino"

Stephen Covey 


\section{LISTA DE FIGURAS}

Figura 1 - Recorte parcial da Sonata de Mozart para 2 pianos (k448) em Ré maior. 16

Figura 2 - Representação esquemática do efeito da música nas funções neurais, cognitivas e neuroquímicas, e como a Musicoterapia tem efeito sobre diferentes domínios de funções afetadas após lesão cerebral traumática. 25

Figura 3 - Modelo conceitual geral para potenciais impactos terapêuticos de intervenções baseadas em música. 26

Figura 4 - Disposição do aparelho de som e caixa dos animais que receberam a Sonata de Mozart durantes 4 dias em uma intensidade de $65 \mathrm{db}$. 33

Figura 5 - Teste do Campo aberto 34

Figura 6 - Teste do Labirinto em Cruz Elevado. 35

Figura 7 - Teste do Nado forçado.. 36

Figura 8 - Esquiva inibitória tipo Step-down

Figura 9 - Delineamento experimental. 38

Figura 10 - Atividade locomotora de ratos avaliada no Teste do Campo aberto..43

Figura 11 - Comportamento relacionado à ansiedade de ratos avaliados no teste do Labirinto em Cruz Elevado.

Figura 12 - Comportamento sugestivo de Depressão/estresse em ratos avaliados no Teste do Nado Forçado. 50

Figura 13 - Memória de curta e longa duração em ratos avaliados no teste de Esquiva Inibitória. 53 


\section{LISTA DE TABELAS}

Tabela 1 - Média dos quadrantes percorridos nas diferentes faixas etárias e comparação entre pares de idade.

Tabela 2 - Interação entre as variáveis independentes e sua significância no Teste do Campo aberto.

Tabela 3 - Média do percentual de entrada nos braços abertos do LCE nas diferentes faixas etárias e comparação entre pares de idade.

Tabela 4 - Interação entre as variáveis independentes e sua significância no LCE (percentual de entrada nos braços abertos).

Tabela 5 - Média do percentual de permanência nos braços abertos do LCE nas diferentes faixas etárias e comparação entre pares de idade.

Tabela 6 - Interação entre as variáveis independentes e sua significância no LCE (percentual de permanência nos braços abertos). 46

Tabela 7 - Média da frequência de entrada nos braços fechados do LCE nas diferentes faixas etárias e comparação entre pares de idade.

Tabela 8 - Interação entre as variáveis independentes e sua significância no LCE (frequência de entrada nos braços fechados)

Tabela 9 - Tempo médio de imobilidade nas diferentes faixas etárias e comparação entre pares de idade

Tabela 10 - Interação entre as variáveis independentes e sua significância no Teste do Nado Forçado. 49

Tabela 11 - Tempo médio de descida da plataforma nas diferentes faixas etárias e comparação entre pares de idade

Tabela 12 - Interação entre as variáveis independentes e sua significância no Teste da Esquiva Inibitória do tipo Step Down (Memória de curta duração).

Tabela 13 - Interação entre as variáveis independentes e sua significância no Teste da Esquiva Inibitória do tipo Step Down (Memória de longa duração)..... .52 


\section{LISTA DE ABREVIATURAS}

ANOVA

Análise de Variância

EBA.

Entradas nos braços abertos

EBF.

Entradas nos braços fechados

CEUA Comitê de Ética no Uso Animal

LCE Labirinto em Cruz Elevado

LTP Potenciação de longo prazo

LTD Depressão de longo prazo

MCD Memória de curta duração

MLD Memória de longa duração

SNC Sistema Nervoso Central TBA Tempo nos braços abertos

TBF Tempo nos braços fechados 


\section{RESUMO}

A depressão, a ansiedade e os prejuízos cognitivos são encontrados com frequência em pacientes com diversas patologias. Existem várias intervenções terapêuticas disponíveis como, por exemplo, a música, que pode ser utilizada como ferramenta na reabilitação de pacientes com alguns desses tipos de manifestações clínicas. A Musicoterapia utiliza o som para alcançar propriedades terapêuticas, psicoprofiláticas e/ou de reabilitação. O uso da música, por meio desta técnica, tem demonstrado melhorias na atenção, motivação, relaxamento e vocalização. Desta maneira, considerando o poder restaurador da música, esta pesquisa foi conduzida para investigar a influência da Musicoterapia no comportamento de ratos, em diferentes fases de desenvolvimento. Para tal, foram utilizados ratos Wistar machos $(n=10)$ e fêmeas $(n=10)$, em condições padronizadas de laboratório. Os procedimentos foram realizados quando os animais estavam com cerca de 1 mês de idade e repetidos quando eles completaram 2, 3 e 4 meses, sendo divididos em dois grupos: 1) Controle, e 2) Musicoterapia. Para este último grupo, a Sonata de Mozart para 2 Pianos foi tocada em um intensidade de som de 65 decibéis durante quatro horas por dia, sendo duas horas pela manhã e duas horas pela tarde (intervalo de aproximadamente 12 horas, por 4 dias), quando os animais atingiram cada idade. Os testes experimentais utilizados foram: Campo Aberto (locomoção), Labirinto em Cruz Elevado - LCE (ansiedade), Nado Forçado (depressão/estresse) e Esquiva Inibitória (memória). Foi observado no teste do Campo Aberto, que quanto maior eram as idades dos ratos machos, menores eram as suas medidas de locomoção. Nesse caso, os ratos com quatro meses locomoveram-se significantemente menos do que nas demais idades. No LCE, os ratos fêmeas que receberam música com 1, 2 e 3 meses de idade aumentaram o percentual de tempo nos braços abertos do labirinto, enquanto que os ratos machos com 1 mês de idade reduziram esse parâmetro. No Nado Forçado as diferenças estatísticas foram observadas somente com 1 mês de idade para ambos os sexos, onde as fêmeas aumentaram o tempo de imobilidade no tanque, enquanto os machos reduziram esse parâmetro após a Sonata de Mozart. Por fim, na Esquiva Inibitória, observou-se uma melhora da memória de forma dependente da idade. Com base nestes resultados, sugere-se que a Musicoterapia baseada na Sonata de Mozart pode produzir efeito ansiolítico (em ratos fêmeas) ou ansiogênico (em ratos machos). Em contrapartida, os comportamentos relacionados ao nível de estresse/depressão foram observados somente nos animais com 1 mês de idade, para ambos os sexos, visto que os machos tenderam a ter maior nível de estresse, enquanto as fêmeas ficaram mais apáticas e imóveis. No que diz respeito aos aspectos cognitivos dos animais, o aumento no tempo de permanência na plataforma, pode ter sido em decorrência do processo adaptativo decorrente das sucessivas repetições dos testes, não em decorrência da terapia com a Sonata de Mozart. Desta maneira, sugere-se que a música, na maioria das vezes, tem poder de intervir de forma positiva a minimizar as alterações comportamentais relacionadas principalmente com a ansiedade e a depressão.

Palavras-chave: Ansiedade; Depressão; Locomoção; Memória; Musicoterapia. 


\begin{abstract}
Depression, anxiety and cognitive impairments are frequently found in patients with various pathologies. There are various therapeutic interventions available for these cases, for example music, which may be used as a tool in the rehabilitation of patients with certain types of these clinical manifestations. Music therapy uses sound to reach therapeutic, psychoprophylactic and/or rehabilitation properties. The use of music by this technique has been providing improvements in attention, motivation, relaxation and vocalization of patients in need. Thus, considering the healing power of music, this research was conducted to investigate the influence of music therapy on the behavior of rats at different stages of development. Thus, male $(n=10)$ and female $(n=10)$ Wistar rats under standard laboratory conditions were used. The procedures were performed when animals were approximately 1 month of age, and repeated once they completed 2, 3 and 4 months, being divided into two groups: 1) control and 2) music therapy. For this last group, the Mozart Piano Sonata 2 was played at a sound intensity of $65 \mathrm{~dB}$ for four hours per day, two hours in the morning and two hours in the afternoon (12 hours, for 4 days) when the animals reached each age. The experimental tests were: the Open Field (locomotion), the Elevated Plus-Maze - EPM (anxiety), the Forced Swimming (depression/stress) and the Inhibitory Avoidance (memory) tests. It was observed that in the Open Field test the locomotion was inversely proportional to age. In this case, the locomotion in rats with four months old was significantly less than in other ages. In the EPM tes, female rats with 1,2 and 3 months old, which were exposed to music, increased the percentage of open arms time in the maze while male rats with 1 month old reduced such parameter. In the Forced Swimming test, the statistical differences were observed only when both genders were 1 month old. Females increased immobility time in the tank, whereas males reduced the same parameter by listening to Mozart's Sonata. Finally, in the Inhibitory Avoidance test, an improvement age-dependent memory was observed. Based on these results, Music therapy related to Mozart's Sonata produces anxiolytic (in female rats) or anxiogenic (in male rats) effects. On the other hand, components related to the level of stress/depression were observed only in 1 month old animals, for both genders, considering that males probably have higher stress level, while females were more apathetic and static. With regard to the cognitive aspects of animals, the increase in lattency time in the platform of the Inhibitory Avoidance test, may have been due to the adaptive process resulting from successive repetitions of the test, not due to therapy with Mozart Sonata. Thus, it was concluded that music, in most cases, is able to interfere in a positive way to minimize behavioral disorders, mainly related to anxiety and depression
\end{abstract}

Keywords: Anxiety; Depression; Immobility; Memory; Music Therapy. 


\section{SUMÁRIO}

1 INTRODUÇÃO

1.1 ANSIEDADE

1.2 DEPRESSÃO

1.3 COGNIÇÃO

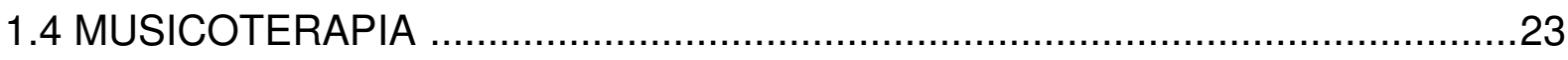

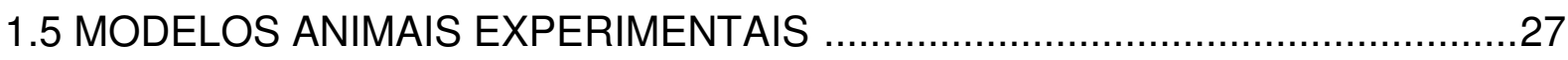

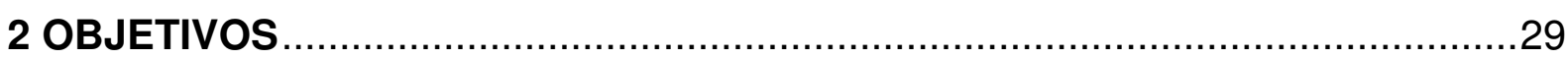

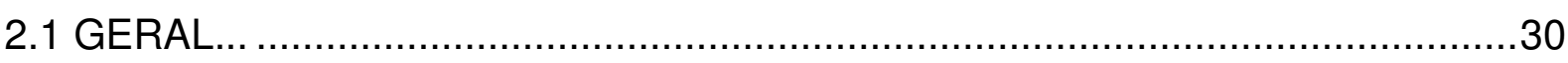

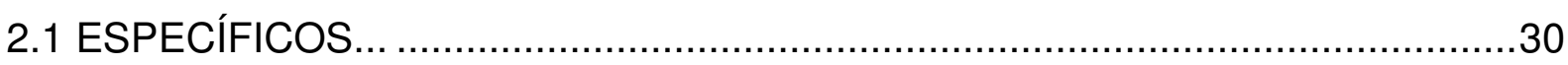

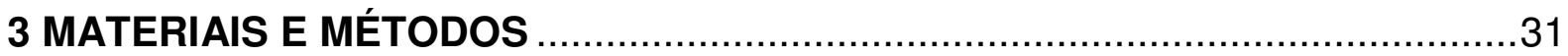

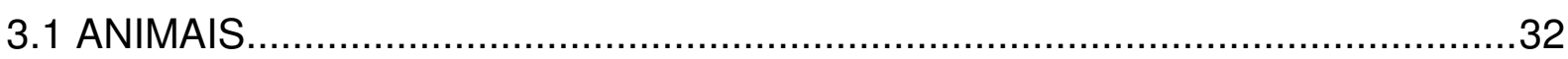

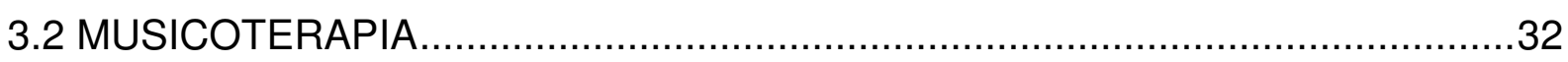

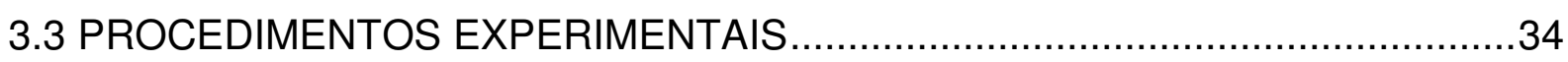

3.3.1 Teste do Campo aberto ………………........................................................................... 34

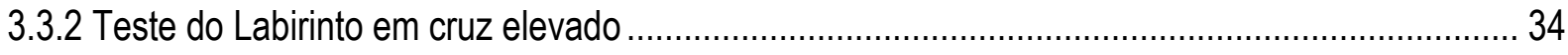

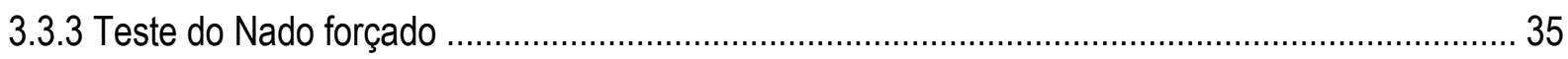

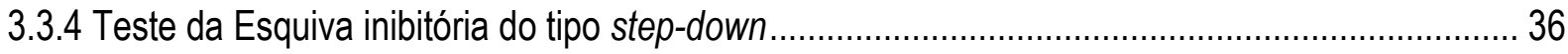

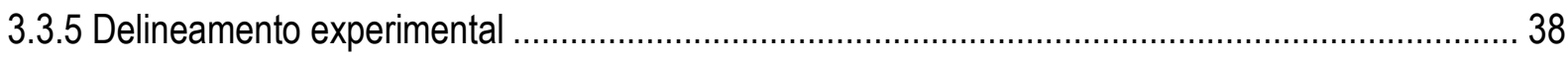

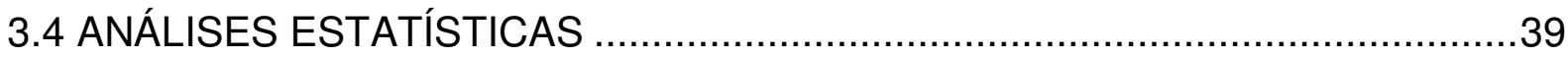

4 RESULTADOS

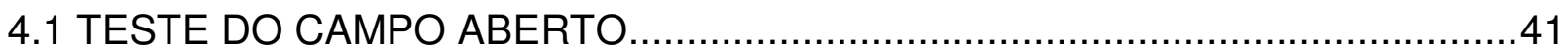

4.2 TESTE DO LABIRINTO EM CRUZ ELEVADO ….........................................43

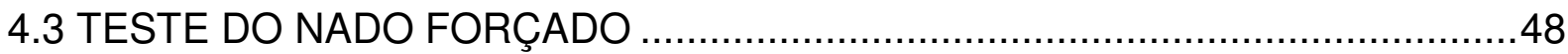

4.4 TESTE DA ESQUIVA INIBITÓRIA DO TIPO STEP-DOWN ............................51

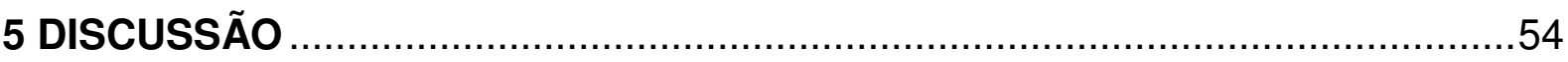

6 CONCLUSÕES

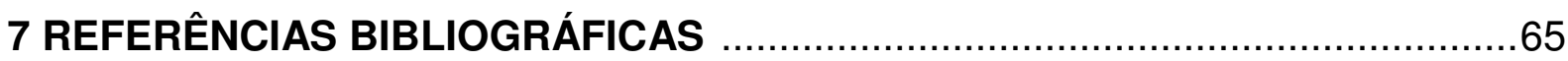

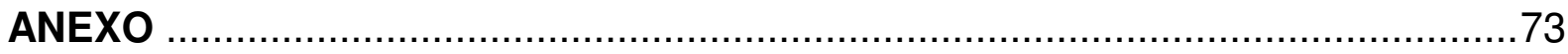

Comprovante do Comitê de Ética no Uso Animal (CEUA) ........................................74 


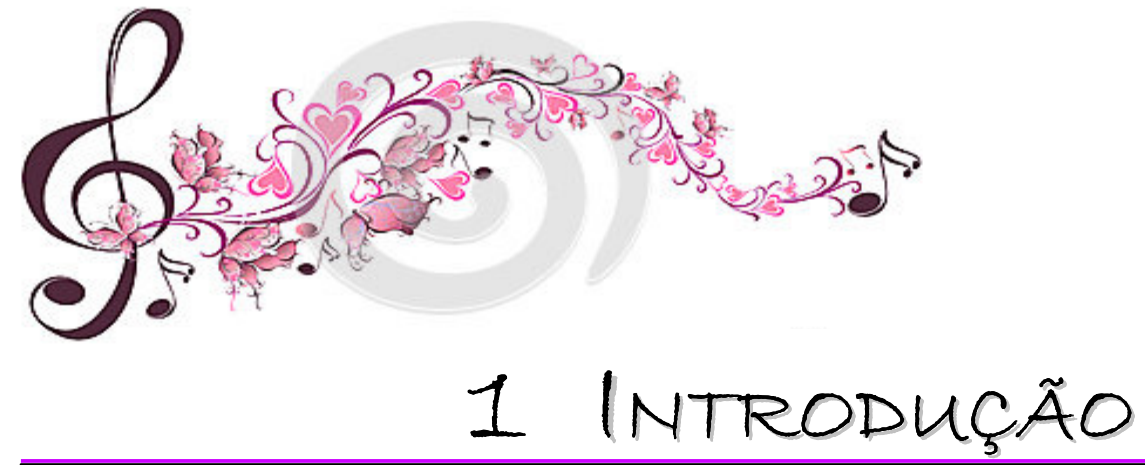


A ansiedade, a depressão e os déficits cognitivos são encontrados, com frequência, em pacientes com várias patologias clínicas e isso, geralmente, leva a uma diminuição da qualidade de vida (CHOl et al., 2008). Atualmente, existem várias intervenções terapêuticas disponíveis para serem utilizadas na reabilitação de indivíduos que têm algumas destas manifestações psicocomportamentais (CHOl et al., 2008; KIM at al., 2011).

Os debates sobre a origem e a função da música têm uma longa história e, provavelmente, interferem de forma positiva contra algumas dessas sintomatologias citadas previamente. Enquanto alguns cientistas argumentam que ela não desempenha papel adaptativo na evolução humana, outros sugerem que tem um claro papel evolutivo e apontam para sua universalidade (MASATAKA e PERLOVSKY, 2012). Dessa forma, a música vem sendo amplamente utilizada para o tratamento e assistência em várias doenças (KAMIOKA et al., 2014).

A Musicoterapia, portanto, exerce alterações fisiológicas no Sistema Nervoso Central (SNC), uma vez que é uma técnica de tratamento que utiliza o som para fins psicoprofiláticos e de reabilitação. Assim, ela vem sendo utilizada de forma significativa e eficiente para diminuir complicações psicocomportamentais (TASSET et al., 2012). Essas atividades devem-se ao fato de que a música acelera a ativação dos circuitos neurais em várias áreas cerebrais ligadas ao comportamento emocional, como o hipocampo e córtex préfrontal (KRUMHANSL, 1997).

A música pode também modular a atividade de vários neurotransmissores químicos no SNC, principalmente a dopaminérgica nas estruturas mesolímbicas, as quais, em conjunto com as áreas previamente mencionadas, estão diretamente ligadas aos processos de reforçamento cerebrais em respostas aos efeitos emocionais prazerosos (TASSET et al., 2012). Além disso, sabe-se que em seres humanos, os níveis hormonais parecem ter um envolvimento com as respostas comportamentais e cognitivas, reduzindo seus níveis, de modo a afetar essas respostas em idades mais avançadas (FUKUI et al., 2012).

É provável que a interpretação da música pelo cérebro possa responder de forma diferente, dependendo da fase da vida, visto que na infância cada neurônio 
do sistema auditivo forma muitas conexões com outros neurônios, criando uma verdadeira rede neuronal (TRAINOR, 2008).

Cientistas sugerem que ouvir Mozart, por exemplo, ajuda a organizar os padrões de estímulo dos neurônios no córtex cerebral, fortalecendo os processos criativos do hemisfério direito associados ao raciocínio espaço-temporal. A audição deste tipo de música age como uma espécie de exercício para facilitar as operações de simetria associadas à função superior do cérebro e melhorar a concentração (CAMPBELL, 2001). A referida Sonata (Figura 1) tem apresentado efeito modulatório na atividade cerebral (ANGELUCCI et al., 2007; TASSET et al., 2012).

Analisando musicalmente e de forma breve, a Partitura citada a seguir, a tonalidade maior, ainda que apresente variações harmônicas ocasionais, traduz apoio nas resoluções de suas cadências, o que se pode associar à estabilidade. O piano, por si só, tem sonoridade leve, principalmente com Mozart que usa baixo de Albert como apoio harmônico, poucos acordes e região médio-aguda. Isso já produz alguma igualdade tímbrica no decorrer da peça que, com a tonalidade, traduz sonoridade agradável e harmônica aos ouvidos. Quanto aos seus movimentos, no primeiro, o vigor do tema contrapõe com a doçura no desenvolvimento das frases. Leveza contrapondo à precisão rítmica nesse andamento que ele chamou de "Allegro com Spirito". Pode-se associar à alegria, à disposição e ao movimento que nos impulsiona à vida. Já o segundo, ainda que mais calmo pelo andamento "Andante", mantém a característica de fluidez e agilidade tão presentes em Mozart. Fluência melódica, delicadeza em tonalidade maior que propõe lirismo em movimento circular pelas suas resoluções harmônicas. Propõe uma sensação de relaxamento pelo belo conteúdo melódico e leveza. Por fim, o terceiro, "Allegro Molto", aparenta alegria pela agilidade das notas sempre levando a conclusões harmônicas que oferecem repouso. Melodia simples, fácil de ser absorvida, retrata alegria e, até mesmo, um caráter de brincadeira que contagia (CAMPBELL, 2001). 


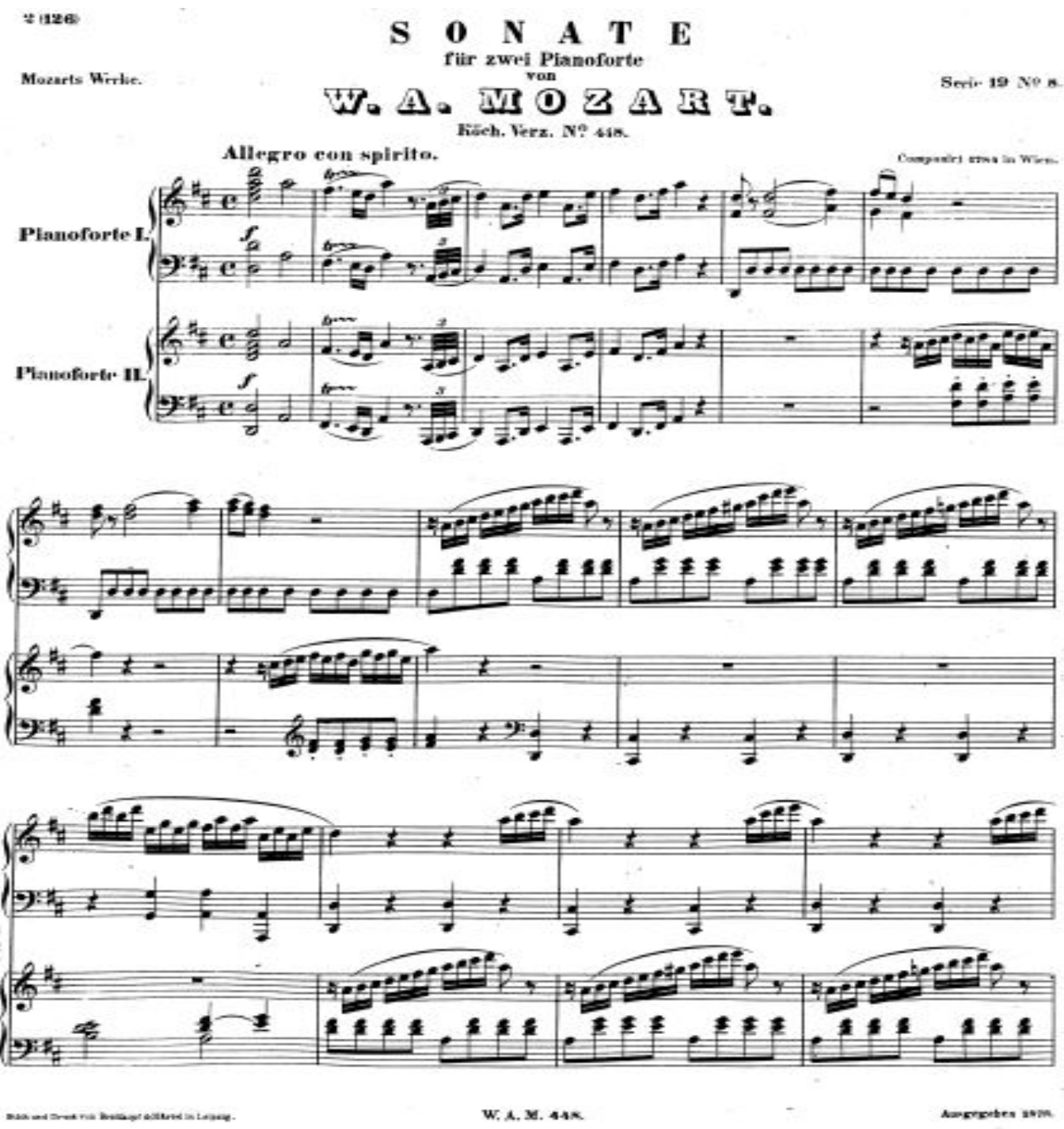

Figura 1: Recorte parcial da Sonata de Mozart para 2 pianos (k448) em Ré maior, que traduz precisão (ritmo sempre regular), leveza (frases melódicas delineadas por notas rápidas), simplicidade no fraseado (o que nos leva absorver com facilidade), intensidades que acompanham uma harmonia tonalmente estruturada e sem tantas surpresas (característica própria da época, o que traz aos nossos ouvidos certo conforto) (Fonte: BREITKOPF e LEIPZIG, 1878).

Com base nessas informações e levando em consideração o poder restaurador da música, foi de nosso interesse investigar, experimentalmente, a influência da Musicoterapia, no comportamento de ratos em desenvolvimento, isto porque, até onde é de nosso conhecimento, nenhum trabalho investigou se existem variações nestas respostas que sejam dependentes da idade de um sujeito experimental. 


\subsection{ANSIEDADE}

Ansiedade pode ser definida como um estado de medo desenvolvido em antecipação a uma ameaça, que promove a vigilância e facilita comportamento evasivo. Propôe-se uma distinção entre traço e estado de ansiedade, com o primeiro sendo um estado emocional constante que pode se tornar patológico e o último sendo saudável, consequência momentânea de um estímulo ansiogênico. Alguns autores, no entanto, sugerem que traço de ansiedade é condicionado pela intensidade e frequência dos episódios de estado de ansiedade. Quando esses sentimentos são exagerados eles podem interromper o funcionamento da vida, sendo assim classificados como transtornos de ansiedade, o mais prevalente grupo de distúrbios na população humana (MEDEIROS et al., 2013; SADOCK e SADOCK, 2007).

É bem conhecido o fato de essa manifestação clínica ser produto da interação de fatores genéticos e ambientais. Dentre estes últimos, chama-se a atenção ao fato de que o estresse é um dos principais sintomas que favorece a ansiedade. A experiência de estresse surge quando um indivíduo percebe as demandas do ambiente, sendo reguladas pelos processos descendentes do SNC, bem como por processos subcorticais dentro do sistema límbico, que encaminham suas mensagens por meio de vias neuronais para um sistema de controle central, que envolve o eixo hipotálamo-hipófise-supra renal (THOMA et al., 2013).

Com o tempo, novas estruturas foram incorporadas ao sistema límbico, que passaram a serem consideradas como parte do SNC que coordena 0 funcionamento das vísceras a as emoções. Foi dada uma conotação neuroquímica ao conceito de sistema límbico, ao destacar que o conjunto de estruturas nucleares que o constituem são ricas em neuropeptídeos, enquanto que estruturas adjacentes contêm monoaminas, como noradrenalina, dopamina e serotonina. Os neurônios monoaminérgicos projetam-se difusamente para quase todas as estruturas límbicas, o que sugere um papel regulador amplo dessas aminas sobre as funções do sistema límbico (GRAEFF, 1999). 
O conhecimento atual das estruturas envolvidas na regulação da ansiedade baseia-se tanto em evidências clínicas quanto experimentais, obtidas em seres humanos e animais de laboratório. No que diz respeito ao medo e à ansiedade, a perspectiva evolutiva leva a pensar que tais emoções estão associadas a diferentes estratégias de defesa, que ocorrem em resposta a perigos que determinada espécie animal encontra, invariavelmente, em seu nicho ecológico (GRAEFF, 1999; HIGA-MCMILLAN et al., 2015).

Dependendo da fase da vida, observa-se uma maior suscetibilidade aos transtornos de ansiedade em alguns indivíduos, devido potencialmente às mudanças na produção do hormônio gonadal e adrenal. Muitas alternativas são adotadas com intuito de reduzir os níveis de ansiedade. Os medicamentos sintéticos, normalmente, são eficazes para reduzir as sintomatologias dessa manifestação psicológica. Com o objetivo de tratar a ansiedade patológica, através do uso de diferentes alternativas farmacológicas que vão agir nas diversas estruturas do sistema límbido e neurotransmissores, os benzodiazepínicos destacam-se pela sua ampla margem de segurança, ainda que não sejam destituídos de efeitos colaterais ou de potencial de abuso. Sua atividade ansiolítica é alcançada com doses que não induzem depressão respiratória clinicamente significativa. O diazepam é o principal representante dessa classe (WECKER e CATALANO, 2006).

O que se observa nesses tipos de tratamentos farmacológicos é que os pacientes ficam sujeitos aos eventos adversos, que acabam levando ao abandono do tratamento. Assim, recursos não farmacológicos são adotados com intuito de melhorar a qualidade de vida desses pacientes (LYNN e BROWN, 2010).

Embora as pesquisas envolvendo a ansiedade humana possam também ser reproduzidas em animais de laboratório, pouco é conhecido sobre este comportamento em roedores, sob a influência da música. Desta forma, surgem estudos com interesse em investigar a ontogenia desse comportamento similar ao de ansiedade em ratos, envolvendo diferentes faixas etárias que representam a infância, a adolescência e a fase adulta. 


\subsection{DEPRESSÃO}

Os transtornos de humor referem-se aos estados emocionais, consistindo de um conjunto de sinais e sintomas persistentes por semanas ou meses, que representam um desvio marcante do desempenho habitual do indivíduo. O estado de humor pode-se apresentar normal, elevado ou deprimido. O indivíduo também experimenta pelo menos quatro sintomas de uma lista que inclui mudanças no apetite e no peso, alteração do sono, falta de energia, sentimentos de culpa, dificuldades para pensar e tomar decisões, além de pensamentos recorrentes de morte e suicídio (SADOCK e SADOCK, 2007).

O Transtorno Depressivo Maior é uma das principais causas de incapacidade em países desenvolvidos, sendo projetado a se tornar em 2020 a segunda doença mais incapacitante em todo o mundo. Encontra-se em quarto lugar entre todos os transtornos psiquiátricos e médicos, quando consideradas as suas complicações. No entanto, resultados de estudos anteriores indicam também que muitos pacientes ainda sofrem de sintomas residuais e são propensos a recaídas dentro de dois anos após o tratamento. Esses achados indicam a necessidade de melhorar as alternativas psicoterápicas atuais para referida doença (EHRET et al., 2014; EISENDRATH et al., 2014).

Todas as pessoas, homens e mulheres, de qualquer faixa etária, podem ser atingidas por esse distúrbio, sendo as mulheres duas vezes mais afetadas que os homens. Uma em cada quatro mulheres e um em cada seis homens já experimentou depressão durante a sua vida e até $65 \%$ dos indivíduos têm episódios recorrentes. $\mathrm{O}$ desenvolvimento de ferramentas para avaliar a atividade neural, a biologia periférica, a variação genética e a expressão gênica tem sido extremamente impactante neste contexto, porque ajudam a identificar caminhos que podem vincular o ambiente social externo aos processos biológicos internos que têm a capacidade de promover a depressão (SLAVICH e IRWIM, 2014).

Essa doença cerca de 3 a $5 \%$ das crianças e dos adolescentes, interferindo negativamente no crescimento e desenvolvimento, afetando o desempenho escolar e reação familiar, podendo levar inclusive ao suicídio. $\mathrm{O}$ critério para o 
diagnóstico da depressão em crianças e adolescentes são essencialmente os mesmos daqueles para adultos, entretanto a expressão de sintomas pode variar com o estágio de desenvolvimento. Se a terapia cognitiva não é disponível, os antidepressivos podem ser considerados (BHATIA e BHATIA, 2007).

A terapia cognitiva é uma intervenção mente-corpo, que integra meditação com conceitos de terapia comportamental cognitiva desenvolvida especificamente como uma intervenção de prevenção de recaída para este tipo de transtorno (EISENDRATH et al., 2014). O conceito de Modelo Cognitivo explica a depressão pela tríade cognitiva, pelos esquemas e pelos erros cognitivos. O primeiro componente é a visão negativa que o paciente tem de si mesmo. O segundo consiste na tendência de interpretar suas experiências atuais de uma forma negativa e, por fim, o terceiro tem uma visão negativa do futuro. Em relação aos esquemas, o indivíduo presta atenção seletivamente aos estímulos específicos, diante de um conjunto deles, combinando-os em um padrão e posteriormente, conceituado a situação. Sendo assim, uma pessoa específica tende a ser consistente em suas respostas a tipos de eventos semelhantes (BECK et al., 1997).

Há várias alternativas terapêuticas para tratar a depressão. O lítio ainda é usado no tratamento de longa duração dos transtornos afetivos unipolares e também por sua eficácia no tratamento do transtorno afetivo bipolar e depressão resistente (CIPRIANI et al., 2006). Entretanto, vêm aumentando o consumo de inibidores de recaptação de serotonina, como a fluoxetina devido ao fato de também tratar a ansiedade de adultos e crianças (SCHMAUSS, 2015; SINGH et al., 2015). Além disso, ela melhora a memória e promove a neurogênese no hipocampo (MOWLA et al., 2007).

Observa-se, portanto, que mesmo diante dessas alternativas terapêuticas, fica difícil muitas vezes de se observar uma eficácia esperada no tratamento dessa manifestação clínica tanto em adultos quanto em crianças. Assim, cabe aqui o interesse de reproduzir situações que ocorrem em humanos por meio de pesquisa experimental com roedores, a fim de verificar a influência da terapia da música em diferentes fases de desenvolvimento. 


\subsection{COGNIÇÃO}

A cognição consiste em obter, organizar e usar o conhecimento intelectual. É o processamento de uma sequência de operações que envolvem a entrada, o armazenamento e a saída de informações. Recupera e processa dados de memórias armazenadas. As estratégias cognitivas são planos mentais que as pessoas usam para entender a si mesmas e o ambiente. Desta forma, a avaliação clínica da memória deve testar três períodos: a memória imediata que atua em um período de segundos; a recente se aplica a uma escala de minutos a dias, e a remota que abarca meses a anos (SADOCK e SADOCK, 2007).

Fenômenos fundamentais para o aprendizado e memória acontecem no hipocampo, estriado e cerebelo. Estes mecanismos são chamados de Potencial de Longa Duração (LTP, do inglês long term potentiation) e Depressão de Longa Duração (LTD, do ingês long term depression) e estão correlacionados com a plasticidade sináptica, dependentes de óxido nítrico (SUSSWEIN et al., 2004).

Estudos envolvendo a memória demonstram que há diferenças na sua constituição e classificação. McGaugh (1966) estabeleceu o conceito de três sistemas de memória: imediata, de curta duração (que se desenvolve em poucos segundos ou minutos e dura por apenas algumas horas), e de longa duração (que se consolida vagarosamente e é relativamente permanente). A memória imediata dura segundos ou alguns poucos minutos e é identificada como memória de trabalho. A memória de trabalho é primariamente dependente da atividade elétrica das células do córtex pré-frontal, associadas às células de outras regiões do cérebro (GOLD et al., 1975; GOLDMAN-RAKIC, 1992). As memórias de curta e longa duração utilizam sistemas e estruturas complexas para se estabelecer, porém com mecanismos diferentes (IZQUIERDO et al., 1999).

Pacientes com deficiência cognitiva normalmente experimentam má qualidade de vida, associada a um limiar reduzido para lidar com influências ambientais estressantes. Estudos relatam que pacientes com demência têm dificuldade em receber, processar e responder a estímulos ambientais (SAKAMOTO, 2013). Todas as nossas ações e decisões ocorrem em um contexto 
emocional e, portanto, funções cognitivas são influenciadas pelo estado emocional e vice versa (ELLIOTT, 2011).

A memória também é considerada como sendo a capacidade que tem 0 homem e os animais para reterem, recuperarem, armazenarem e evocarem informações disponíveis no SNC. Desta forma, podemos dizer que é a retenção da informação aprendida. Há várias estruturas cerebrais relacionadas à memória, e não há somente um alvo envolvido na aquisição, armazenamento e evocação das diversas informações adquiridas por aprendizagem, tais como: hipocampo, amígdala, córtex entorrinal, giro parahipocampal, fórnix, corpos mamilares, giro do cíngulo, entre outros (BEAR et al, 2002; KANDELL et al., 2000).

As memórias podem também ser classificadas, de acordo com o seu tempo de duração, em memória operacional ou de trabalho (memória imediata que dura segundos ou poucos minutos), memória de curta duração (que se desenvolve em alguns segundos ou minutos e dura várias horas) e memória de longa duração (que consolida lentamente e é relativamente estável). Estas memórias são identificadas como mecanismos separados (EMPTAGE e CAREW, 1993; IZQUIERDO et al, 1999). Esses tipos distintos de memórias podem ser avaliados em estudos animais, usando diferentes testes comportamentais.

A memória social (ou paradigma de reconhecimento) é considerada um bom modelo animal dessa forma de memória em seres humanos que é principalmente gerada, a partir de estímulos olfativos. Esse modelo é baseado no fato de que roedores gastam mais tempo investigando um rato jovem não familiar do que um familiar (DANTZER et al., 1987). Essa memória é prolongada por exposição repetida aos estímulos do rato jovem e prejudicada pela interferência retroativa do estímulo. Isso pode ser facilitado por fármacos que melhoram a memória e interrompido por modelos farmacológicos e patofisiológicos, conhecidos por prejudicar a memória (PREDIGER e TAKAHASHI, 2003, 2005).

Para avaliar de uma maneira mais criteriosa os aspectos cognitivos em faixas etárias que compreendem não somente a infância, mas também a adolescência, fase adulta e avançada, cabe a investigação de alternativas não farmacológicas na melhora dos aspectos cognitivos em diferentes idades. 
1.4 MUSICOTERAPIA: INFLUÊNCIA NA ANSIEDADE, DEPRESSÃO E MEMÓRIA

O uso da música como um método terapêutico tem uma longa história, impulsionada pelo modelo de ciência social, onde ela é interpretada como um facilitador de bem-estar e melhora da saúde emocional. Esta sua natureza, capaz de reduzir o estresse e melhorar a saúde emocional, começou a receber provas científicas de estudos que examinaram as alterações neuroquímicas ocorridas quando se ouve ou se envolve ativamente com ela (HEGDE, 2014).

A intervenção da música é um tipo especial de psicoterapia onde formas de comunicação e interações musicais podem ser utilizadas juntamente com a comunicação verbal. As experiências musicais podem incluir improvisação livre e estruturada e outros tipos ativos de fazer e ouvir música (GOLD, 2009). Ela parece afetar fenômenos fisiológicos, tais como pressão arterial, batimento cardíaco e respiração, bem como aspectos emocionais tais como humor e sentimentos. Estudos clínicos demonstraram correlações entre seus efeitos de estimulação fisiológica e emocional (KIM et al., 2011).

A Musicoterapia, portanto, é uma intervenção sistemática que usa experiências musicais e as relações desenvolvidas para promover a saúde (CARR et al., 2013; WARTH et al., 2014). Assim, ela pode ser produzida ativamente pelo paciente e terapeuta (como improvisação em instrumentos musicais), ou ser receptiva (como ouvir música pré-gravada). O tipo de interação musical, nível de estrutura e quantidade de discussão verbal podem variar dependendo da abordagem do musicoterapeuta, características do paciente e seu diagnóstico. As intervenções podem assumir a forma de terapia em grupos ou individuais e os objetivos irão variar de acordo com suas necessidades específicas (CARR et al., 2013).

Intervenções como cantar e ouvir música, são amplamente aceitas como benéficas para o bem-estar psicológico de pessoas com demência, isto porque elas podem ser valorizadas como acesso fácil e estimulante, bem como podem ser desfrutadas individualmente ou com outras pessoas, mesmo no contexto de 
demência grave. Elas vêm sendo apreciadas e avaliadas como uma atividade social. A capacidade de apreciar e se envolver com música permanecem intactas até mesmo em pacientes que apresentam suas funções cognitivas bem deteriorizadas (MCDERMOTT et. al., 2014).

Este tipo de terapia exige o mínimo de esforço físico e também pode ser uma intervenção ideal para ajudar pacientes com transplante de células-tronco hematopoiéticas a gerenciar suas emoções e controlar o estresse. Ela tem sido usada para aliviar uma ampla gama de sintomas, tais como dificuldades de sono, dor, ansiedade, depressão, fadiga e náuseas, além de aumentar as habilidades de enfrentamento e bem-estar espiritual (RATCLIFF et al., 2014).

Já no que se refere à depressão, o objetivo da terapia envolvendo música é ajudar as pessoas com problemas de Saúde Mental. Geralmente elas não são capazes de usar apenas palavras. A técnica de improvisação desta terapêutica baseia-se em fazer música de forma ativa e espontânea, muitas vezes em uma díade paciente-terapeuta. $O$ método utiliza normalmente expressão não verbal e verbal, enfatizando o significado do processo de lidar com as emoções como uma parte essencial do processo terapêutico (ERKKILA et al., 2008).

A música também ajuda a tolerar o que chamamos de dissonância cognitiva, que é um desconforto produzido pela exploração de cognições contraditórias simultaneamente. As pessoas preferem evitar este desconforto e geralmente o fazem pela desvalorização dos conhecimentos conflitantes. Uma hipótese recente, experimentalmente validada, sugeriu que ela pode ajudar na dissonância cognitiva, reduzindo ou neutralizando os conhecimentos conflitantes na mente (MASATAKA e PERLOVSKY, 2012).

Trabalhar criativamente com vários recursos dinâmicos da música como tom e ritmo envolvem redes de atenção e funções executivas. Desde que a música é conhecida sabe-se do seu poder de envolver todos os processos cognitivos conhecidos, como um fenômeno biológico, proporcionando flexibilidade cognitiva e emocional, dentre outros benefícios, conforme representação esquemática apresentada na Figura 2 (HEGDE, 2014). 


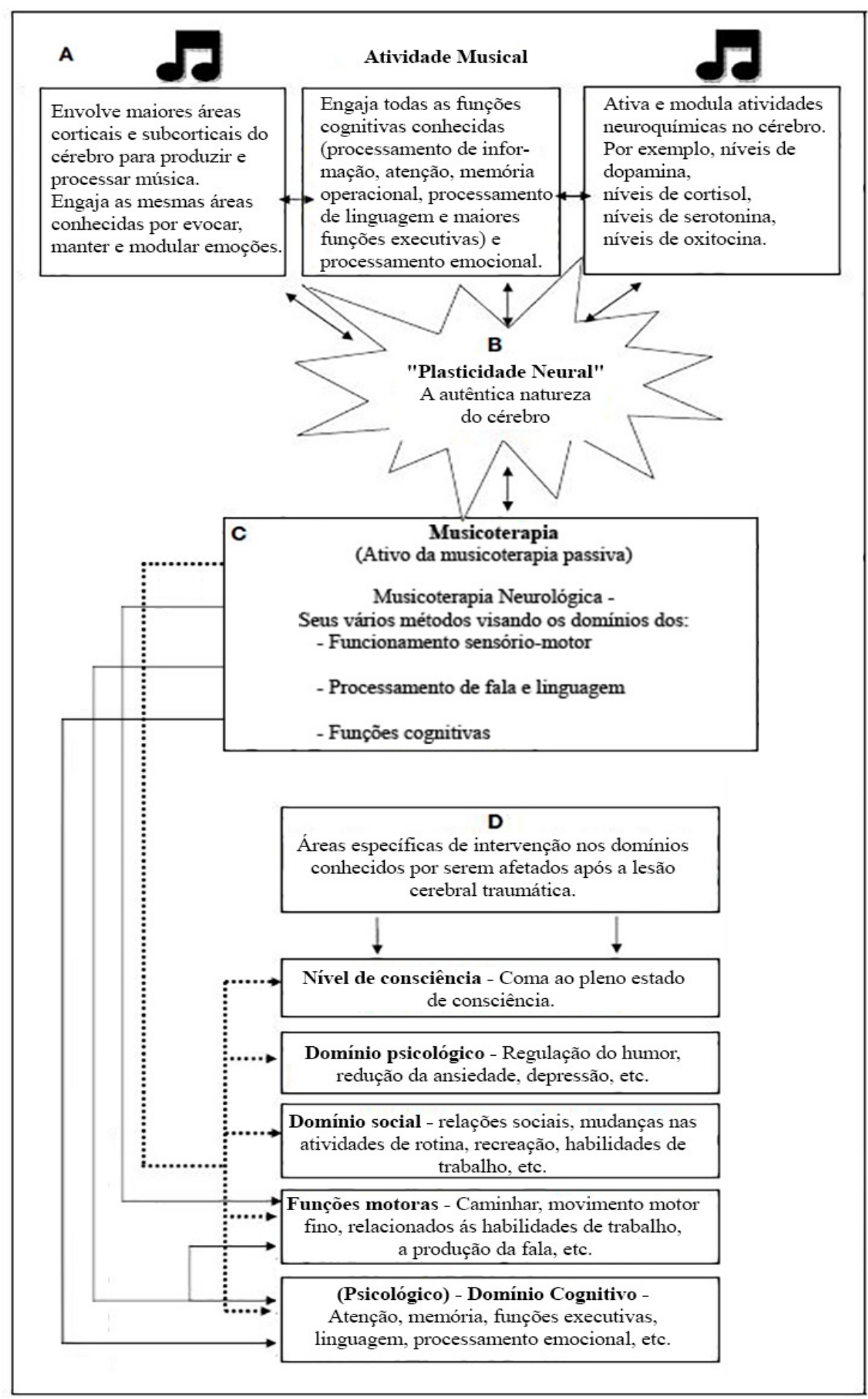

Figura 2: Representação esquemática do efeito da música nas funções neurais, cognitivas e neuroquímicas após uma lesão cerebral traumática. A terapia envolveu atividades baseadas em músicas (ativas e passivas), com efeito sobre diferentes domínios de funções conhecidas (Fonte: modificado de HEGDE, 2014).

Cabe enfatizar também que para o alívio dos sintomas físicos e psicológicos associados à malignidade, os cuidados paliativos têm um papel vital nos pacientes com câncer. Sintomas comuns como dor, ansiedade e transtorno 
do humor podem ser complicados de serem tratados com opções farmacológicas. A busca de intervenções complementares fez com que houvesse um aumento do interesse do uso da música para pacientes nessas condições no âmbito dos cuidados paliativos. Para muitos deles, o diagnóstico de câncer, por exemplo, pode resultar em significativa ansiedade o que pode interferir no sono, gozo da vida, nas relações interpessoais e, nas atividades de diárias da vida cotidiana (ARCHIE et al., 2013). A Figura 3 abaixo representa um modelo dessa situação.

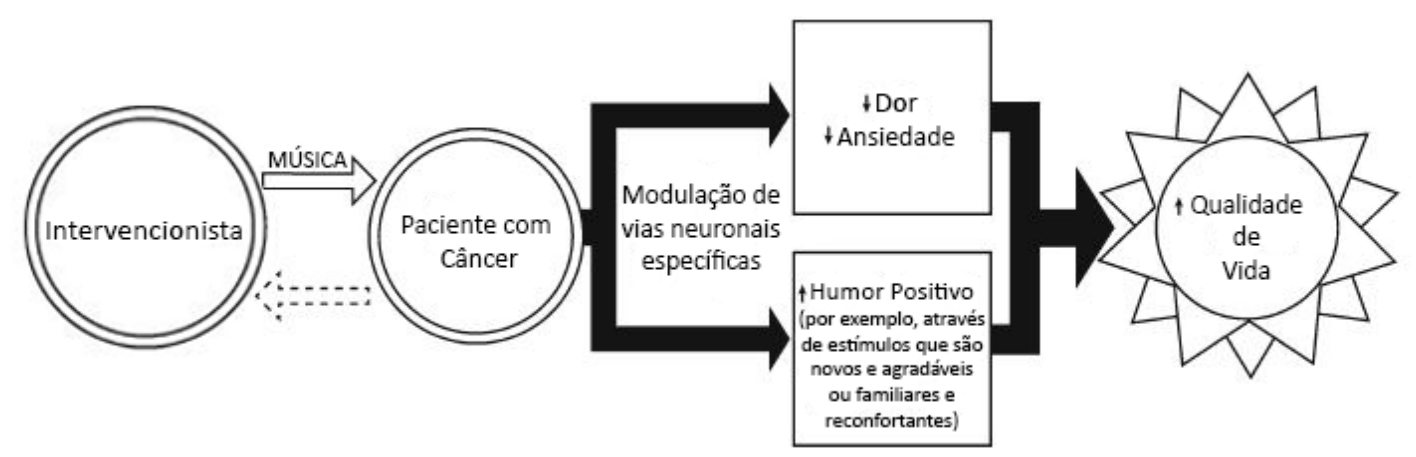

Figura 3: Modelo conceitual geral para os potenciais impactos terapêuticos de intervenções baseadas em música (Fonte: modificado de ARCHIE et al., 2013 ).

Hwa-byung é uma síndrome limitada mais à cultura Coreana, causada pela raiva persistente acumulada no interior do corpo, também chamada como 'Doença do fogo'. É geralmente causada por estresse crônico e os sintomas continuam mesmo na ausência dos fatores que os causaram, levando os pacientes a pensarem na sua improvável cura. Pacientes com Hwa-byung são frequentemente diagnosticados com depressão maior e transtornos de ansiedade. Pode ocorrer um sentimento de superaquecimento, uma sensação de pressão sobre o peito, palpitações, congestão respiratória e insônia. A Musicoterapia foi eficaz em relaxar, sedar e melhorar os sinais vitais desses pacientes. Além disso, na Coréia, foram relatados outros casos onde os sintomas de crianças com transtornos de hiperatividade e déficit de atenção reduziram depois de receber a terapia musical (PARK et al., 2012).

Com base nessas informações, cabe aqui também nosso interesse em investigar a propriedade terapêutica da música no comportamento e cognição de sujeitos experimentais em diferentes fases de desenvolvimento. 


\subsection{MODELOS EXPERIMENTAIS ANIMAIS COMO RECURSOS NAS AVALIAÇÕES COMPORTAMENTAIS E COGNITIVAS}

Conforme discutido previamente e frente a muitas condições com causas variadas, é possível observar prejuízos neuronais, várias alterações comportamentais, como irritabilidade, depressão, ansiedade, dificuldade de concentração e distúrbios relacionados ao aprendizado e memória. Essas alterações são perfeitamente detectáveis não somente em humanos, mas também em animais experimentais. Para tal, nesses últimos utilizam-se equipamentos elaborados para a pesquisa com protocolos validados, de acordo o comportamento a ser analisado e respeitando-se as características inerentes a cada espécie (BOUWKNECHT, 2015; GOLD, 2015; LUCENA et al., 2013; MATTHEWS, 2015).

O uso de modelos animais torna-se fundamental, particularmente quando se demonstra uma analogia relevante entre o modelo e o homem. Através deles é possível realizar pesquisas celulares e moleculares, envolvendo neurotransmissores e receptores, que se constituem em ferramentas fundamentais para um melhor esclarecimento de mecanismos fisiológicos, farmacológicos, bioquímicos, comportamentais e neurobiológicos envolvidos em várias patologias (DELGADO et al., 2006; McBRIDE e LI, 1998).

Tem sido proposto por vários pesquisadores que roedores são motivados a investigar objetos e lugares novos, mas que a novidade também induz medo, o que pode tender a suprimir a exploração ou produzir fuga ativa da situação nova (MONTGOMERY, 1955). Drogas (ou outras manipulações) que reduzem o presumível mecanismo inibitório podem aumentar os níveis de exploração, sem afetar as respostas à novidade (GRAY, 1977). Além disso, em vista das grandes evidências de diferenças sexuais na ansiedade basal e na resposta a certas drogas anti-ansiedade (BLANCHARD et al., 1992), é importante que as manipulações experimentais sejam efetuadas com animais de ambos os sexos.

O labirinto em cruz elevado (LCE) tem sido considerado como um teste sensível para o estudo do efeito ansiolítico e ansiogênico de drogas (GARCÍACÁRDENAS et al., 2015). Ele é baseado, entre outros fatores, na aversão natural 
que roedores apresentam pelos braços abertos do labirinto (MONTGOMERY, 1955). Quando ratos são forçados a permanecerem nos braços abertos mostram manifestações comportamentais e fisiológicas de medo, tais como congelamento, defecação, e aumento nos níveis de corticosteróides plasmáticos (PELLOW et al., 1985) e, como uma consequência, permanecem um tempo maior nos braços fechados. A proporção da exploração total nos braços abertos determina uma medida de ansiedade, de tal modo que o aumento nas percentagens de tempo e de entradas nos braços abertos é considerado como indicativo de ação ansiolítica de drogas (HANDLEY e MITHANI, 1984; PELLOW et al., 1985).

O teste do nado forçado é um outro modelo animal usado para reproduzir aspectos relevantes da depressão humana nas espécies de roedores. Animais que mostram níveis elevados de imobilidade nesse teste assumem um estado patológico de sujeitos deprimidos, o que pode ser explorado pela pesquisa préclínica da depressão, além de ser usado como um modelo para as avaliações dos antidepressivos (ELBATSH, 2015).

A medida da latência avaliada no teste da esquiva inibitória do tipo "stepdown" tem sido um dos modelos experimentais usado por muitos laboratórios na avaliação dos estudos envolvendo aprendizagem e memória (Izquierdo et al., 1999; Maia et al., 2009). O modelo da permite avaliar processos de aprendizagem e memória, tarefas essas que dependem de ativação hipocampal e estão extremamente envolvidas com vários sistemas de neurotransmissores (Cammarota et al., 2004; 2008). Para tal, os parâmetros de avaliação envolvem uma fase de treino e pós-treino e um choque de baixa intensidade, que servirá de estímulo aversivo para que o animal deixe de executar uma determinada tarefa que foi a ele apresentada. Esse procedimento deverá ser lembrado quando da realização de um teste proposto, como mecanismo de retenção da memória.

Sabendo-se que os mecanismos neurais das respostas às circunstâncias que induzem medo, provavelmente são similares em humanos e animais, modelos experimentais animais podem ter um bom valor preditivo das respostas relacionadas aos déficits comportamentais e cognitivos. Cabe aqui o interesse em fazer uso desses modelos animais para investigar a resposta decorrente da terapia da música nessas respostas. 


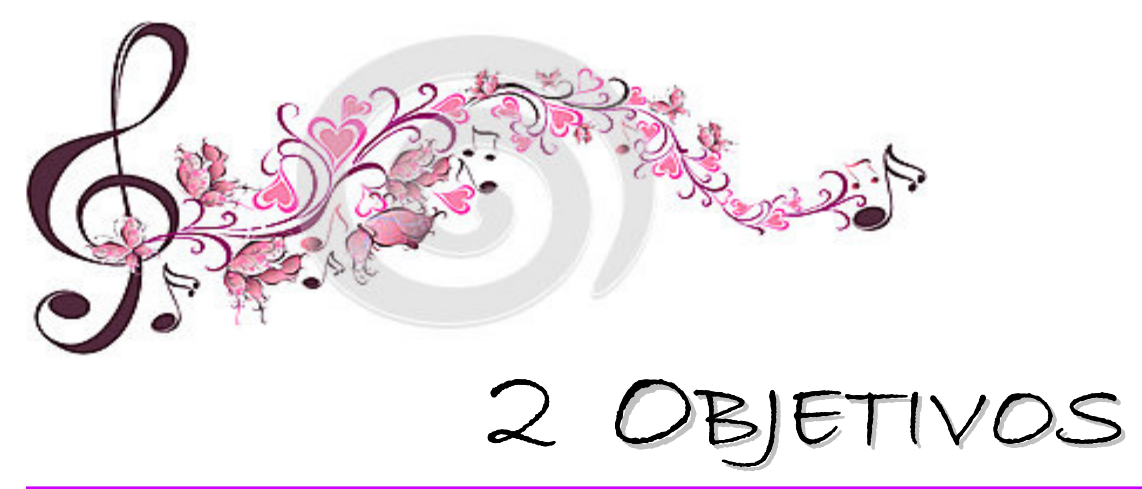




\subsection{GERAL}

Avaliar o efeito da Musicoterapia nos aspectos comportamentais e cognitivos de ratos em diferentes fases de desenvolvimento.

\subsection{ESPECÍFICOS:}

- Observar a influência da música na atividade locomotora de ratos avaliados no Teste do Campo Aberto.

- Verificar o perfil comportamental relacionado à ansiedade de ratos, sob a influência da música, quando avaliados no teste do LCE.

- Analisar os aspectos relacionados aos comportamentos sugestivos de estresse com possíveis componentes depressivos, influenciados pela música, em ratos avaliados no teste do Nado forçado.

- Fazer uma análise comparativa do processo de memorização de curta e longa duração de ratos submetidos à terapia da música quando avaliados no teste da Esquiva Inibitoria. 


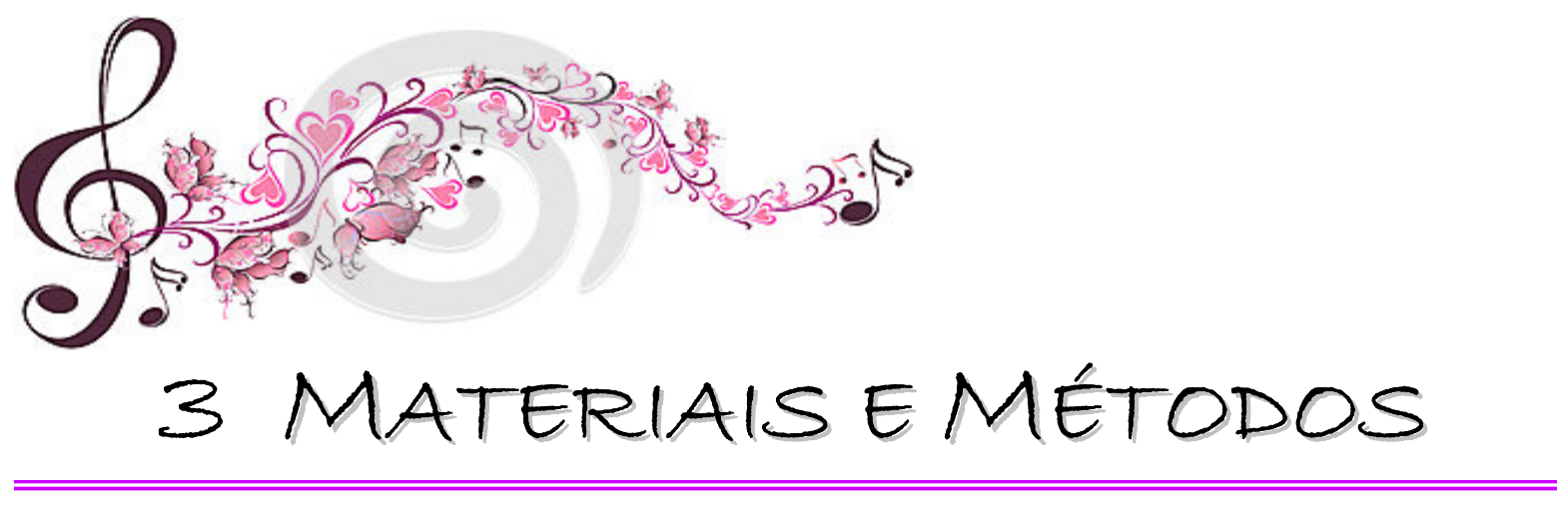




\subsection{ANIMAIS}

Foram utilizados ratos Wistar machos $(n=10)$ e fêmeas $(n=10)$ que chegaram ao Laboratório de Patologia, da Faculdade de Medicina/UnB na última fase de amamentação (21 dias), para que o desmame fosse feito no ambiente do teste, considerando a necessidade de adaptação à área. Essa adaptação foi necessária para reduzir as interferências dos ruídos e estresse decorrentes do transporte provenientes de diferentes ambientes. Os procedimentos foram realizados quando os animais estavam com cerca de 1 mês e repetidos quando eles completaram 2, 3 e 4 meses. Essas idades foram consideradas como correspondentes às fases de criança, adolescente, adulta e idosa, respectivamente, em conformidade com algumas correlações e comparações estabelecidas na literatura (IMHOF et al., 1993; QUINN, 2005).

Para a realização dos testes, os animais foram divididos em dois grupos: 1) Controle, e 2) Musicoterapia, sempre mantidos em condições padronizadas de laboratório com água e ração (marca Presence) ad libitum e obedecendo aos critérios estabelecidos pelo Comitê de Ética no Uso Animal (CEUA), sob o protocolo 80243/2013 (anexo página 74). Todos os experimentos foram conduzidos entre 8:00 e 12:00 horas, com o objetivo de evitar as variações circadianas que poderiam interferir com os resultados experimentais.

\subsection{MUSICOTERAPIA}

Uma sala foi padronizada para receber a Sonata de Mozart, cuja medida de intensidade sonora média de 65 decibéis $(\mathrm{db})$ foi estabelecida por meio de um decibelimetro, marca Minipa, modelo MSI-1325. O arquivo da Sonata de Mozart para dois pianos (K. 448) foi baixado do You Tube, utilizando o site Voobys Vídeos, no formato MP3, utilizando o Software Editor de Áudio (Audacity). A duração do arquivo original era de 22 minutos e 3 segundos. Para se ter um ciclo cuja duração fosse de 2 horas, o arquivo foi repetido 5 vezes e meia. $O$ seu processo de formação constituiu basicamente em colocar cópias da Sonata de forma sequenciada, até se ter uma extensão de duração correspondente a 2 horas. $\mathrm{O}$ arquivo foi salvo em um Pen Drive, para ser adapatado em um aparelho 
emissor de som com entrada USB, que ficava aproximadamente $50 \mathrm{~cm}$ de distância das caixas onde estavam os ratos.

As medidas da intensidade do som foram feitas na lateral de cada caixa para garantir, dessa forma, a mesma intensidade de som para todos os ratos. Além disso, a disposição do aparelho de som intercalado entre duas prateleiras foi também uma forma de garantir o equilíbrio sonoro, conforme demonstrado na Figura 4. A Sonata de Mozart para dois Pianos com seus três movimentos (Allegro con spirito; Andante e Allegro molto), escrita na tonalidade de Ré Maior, foi colocada durante 2 horas no período da manhã e 2 horas a tarde (intervalo de aproximadamente 12h), por 4 dias, quando os animais estavam com cerca de 1 mês e repetidos quando eles completaram 2, 3 e 4 meses de idade. Todos os procedimentos estão de acordo com aqueles descritos na literatura (TASSET et al., 2012).

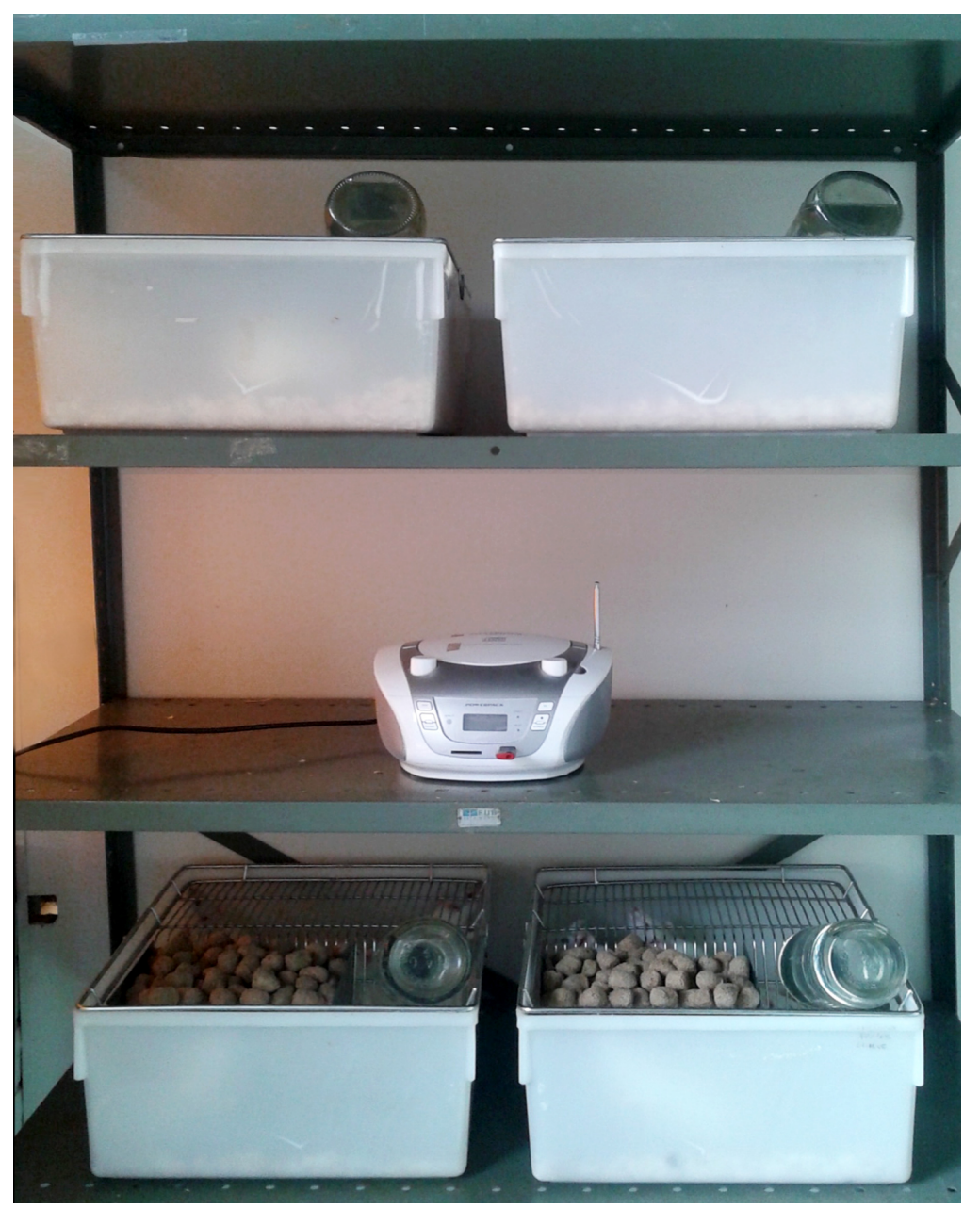

Figura 4: Disposição do aparelho de som e caixas dos animais que receberiam a Sonata de Mozart durante 4 dias em uma intensidade de $65 \mathrm{db}$ sempre que atingiam uma determinada idade (1, 2, 3 ou 4 meses). 


\subsection{PROCEDIMENTOS EXPERIMENTAIS}

\subsubsection{Atividade locomotora espontânea}

Para este teste, foi utilizada uma arena em madeira $(60 \times 60 \times 35 \mathrm{~cm})$, onde 0 chão encontrava-se dividido em 9 quadrantes de $20 \times 20 \mathrm{~cm}$ (Figura 5). Cada animal era posicionado, inicialmente, no quadrante central da arena e testado individualmente por um período de $5 \mathrm{~min}$. Foi considerada atividade locomotora quando cada rato colocava as quatro patas em um novo quadrante (LUCENA et al., 2010; MAIA et al., 2009).

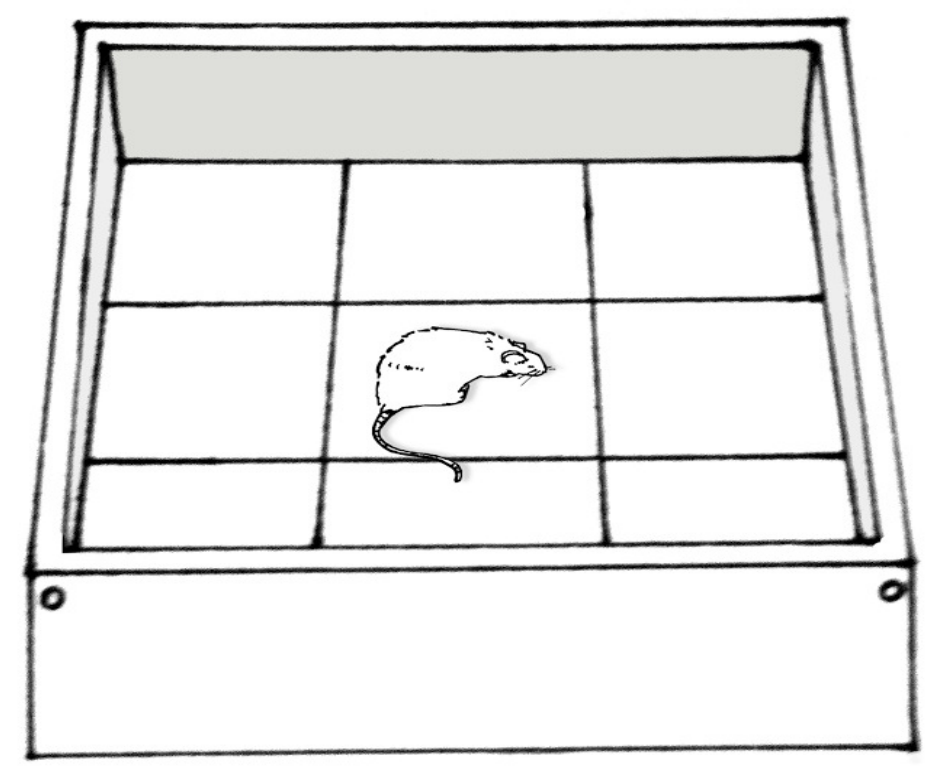

Figura 5 - Teste do Campo aberto - arena dividida em 9 quadrantes para avaliar a atividade locomotora dos ratos posicionados, inicialmente, no centro do aparato para, posteriormente, explorá-la por 5 minutos.

\subsubsection{Labirinto em cruz elevado (LCE)}

É um equipamento em madeira, na forma de cruz, elevado $50 \mathrm{~cm}$ do chão, com dois braços fechados $(50 \times 10 \times 40 \mathrm{~cm})$ e dois abertos $(50 \times 10 \mathrm{~cm})$, opostos entre si (HANDLEY e MITHANI, 1984). Uma proteção de acrílico transparente de $1 \mathrm{~cm}$ de altura circundava os braços abertos para impedir a queda dos animais do LCE (Figura 6). Cada rato era posicionado no centro do labirinto, com a face voltada para um dos braços fechados e colocado para explorar o equipamento por 5 min. Um observador fazia as anotações do número de entradas e do tempo de 
permanência dos animais nos braços abertos e fechados. Após observar cada animal, o LCE era limpo com álcool 10\% (v/v). As percentagens de entradas nos braços abertos eram calculadas em relação ao número total de entradas nos dois braços e também em relação ao tempo de exploração nos braços abertos, em relação ao tempo total do experimento. Para o experimento em questão, o efeito ansiolítico foi definido pelo aumento na proporção do tempo de entradas nos braços abertos, relativo ao tempo total de entradas em ambos os braços (PELLOW et al., 1995).

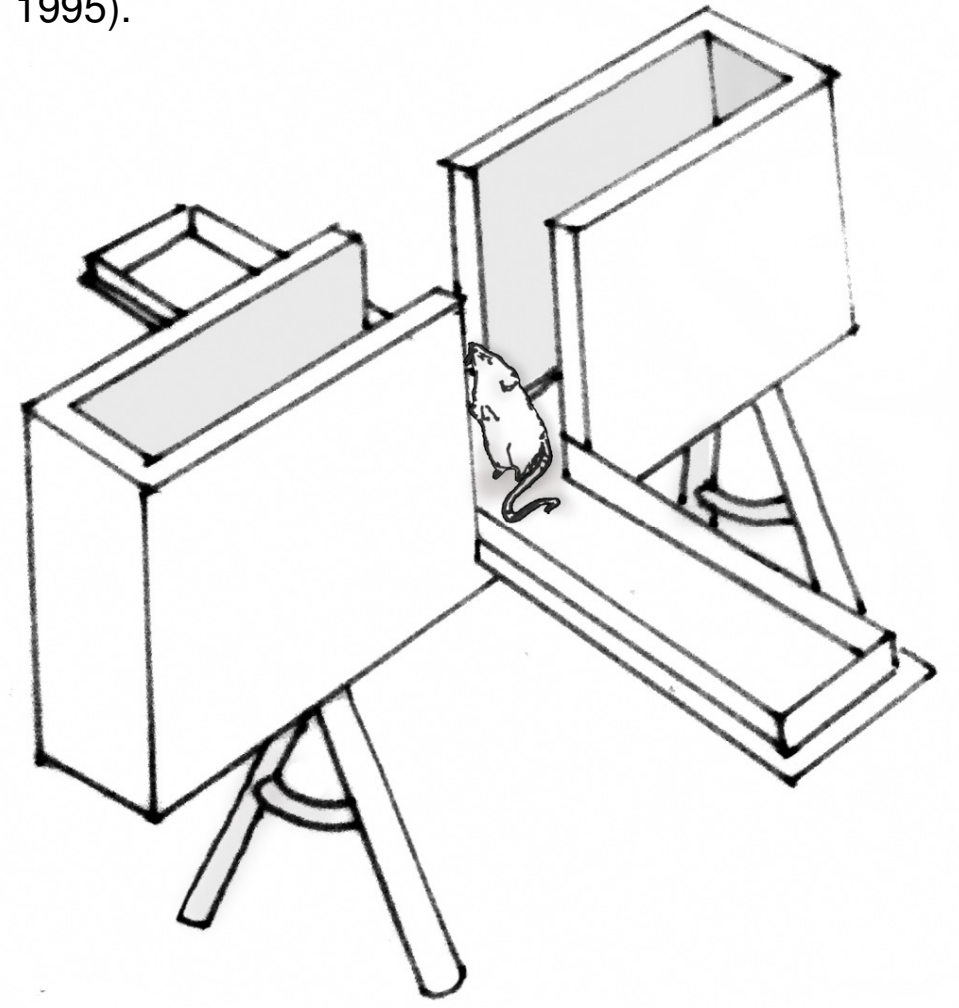

Figura 6 - Teste do Labirinto em cruz elevado utilizado para avaliar o comportamento de ansiedade/estresse dos ratos antes e após receberem a intervenção da Musicoterapia. O rato era colocado no centro do labirindo para poder escolher explorar os braços abertos ou fechados, durante um período de 5 minutos.

\subsubsection{Teste do nado forçado}

Para este teste foi utilizado um cilindro Plexiglass, com $50 \mathrm{~cm}$ de água a uma temperatura de aproximadamente $22 \pm 1^{\circ} \mathrm{C}$ (Figura 7). Os ratos exibiam dois tipos de comportamentos em um tempo de 5 min: fuga, que foi observada nos dois primeiros minutos, para habituação ao teste; e imobilidade contínua nos três últimos minutos, que consistia em observar o tempo em que cada animal permaneceia flutuando, mantendo somente os movimentos mínimos necessários 
para manter a cabeça fora da água (PORSOLT et al., 1978). Esses comportamentos eram avaliados por único pesquisador, para reduzir a variação decorrente da visualização, que era muito subjetiva.

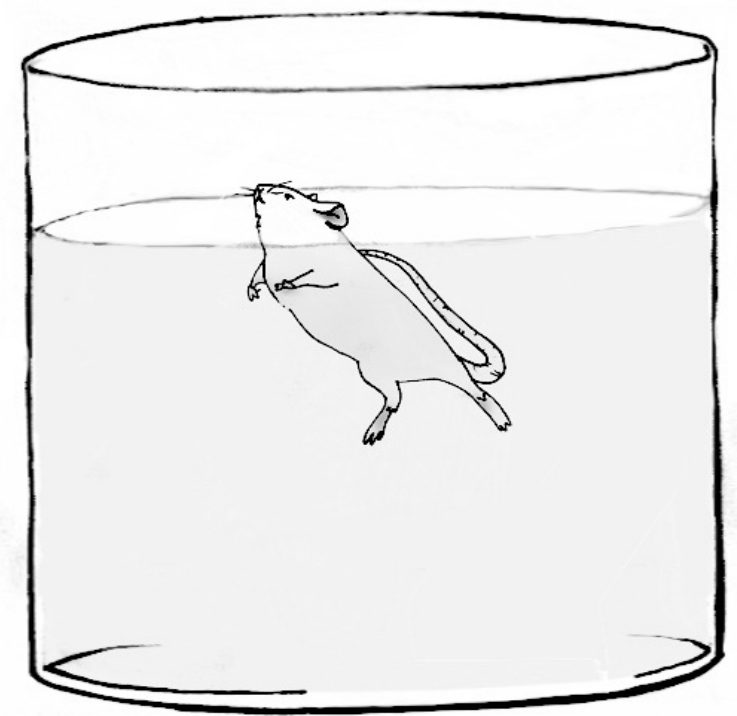

Figura 7 - Teste do Nado forçado, onde os animais permaneciam dentro do tanque com água, por um tempo total de 5 min, onde os 2 primeiros minutos eram para habituação.

\subsubsection{Teste da esquiva inibitória}

O aparelho de esquiva (EP-104 INSIGHT) consistia em uma caixa de vidro e metal, medindo $50 \times 25 \times 25 \mathrm{~cm}$, com uma plataforma de $5 \mathrm{~cm}$ de altura, $8 \mathrm{~cm}$ de largura e $25 \mathrm{~cm}$ comprimento (Figura 8). No lado direito apresentava uma série de barras de alumínio conectadas a um estimulador elétrico, que eram distribuídas com uma distância de $9 \mathrm{~cm}$ entre si, constituindo o assoalho da caixa. Os parâmetros de avaliação envolviam uma fase de treino e pós-treino e um choque de baixa intensidade, que servia de estímulo aversivo para que o animal deixasse de executar uma determinada tarefa que foi a ele apresentada. Esse procedimento devia ser lembrado quando da realização de um teste proposto, como mecanismo de retenção da memória (LUCENA et al., 2013).

No primeiro dia da análise, os animais eram habituados ao aparato, permanecendo no interior do mesmo por $3 \mathrm{~min}$. No segundo dia, eles eram colocados na plataforma em frente ao canto esquerdo da caixa de treino, com a face virada para o lado oposto ao do observador. Assim que o animal descia da 
plataforma da caixa de treino e colocava as quatro patas na grade, recebia um choque de 0,4 $\mathrm{mA}$ por $1 \mathrm{seg}$, sendo retirado imediatamente do aparelho. A memória de curta duração (MCD) foi investigada $1 \mathrm{~h}$ após o treino. Neste teste, $\mathrm{o}$ tempo (latência) máximo de $180 \mathrm{seg}$ em que os animais levavam para descer com as quatro patas da plataforma era utilizado como indicativo de retenção de memória. No terceiro dia, os animais eram novamente colocados na plataforma em frente ao canto esquerdo da caixa de treino para avaliação da memória de longa duração (MLD). Da mesma forma que na MCD, o tempo (latência) máximo de 180 seg foi considerado na análise (LUCENA et al., 2013).

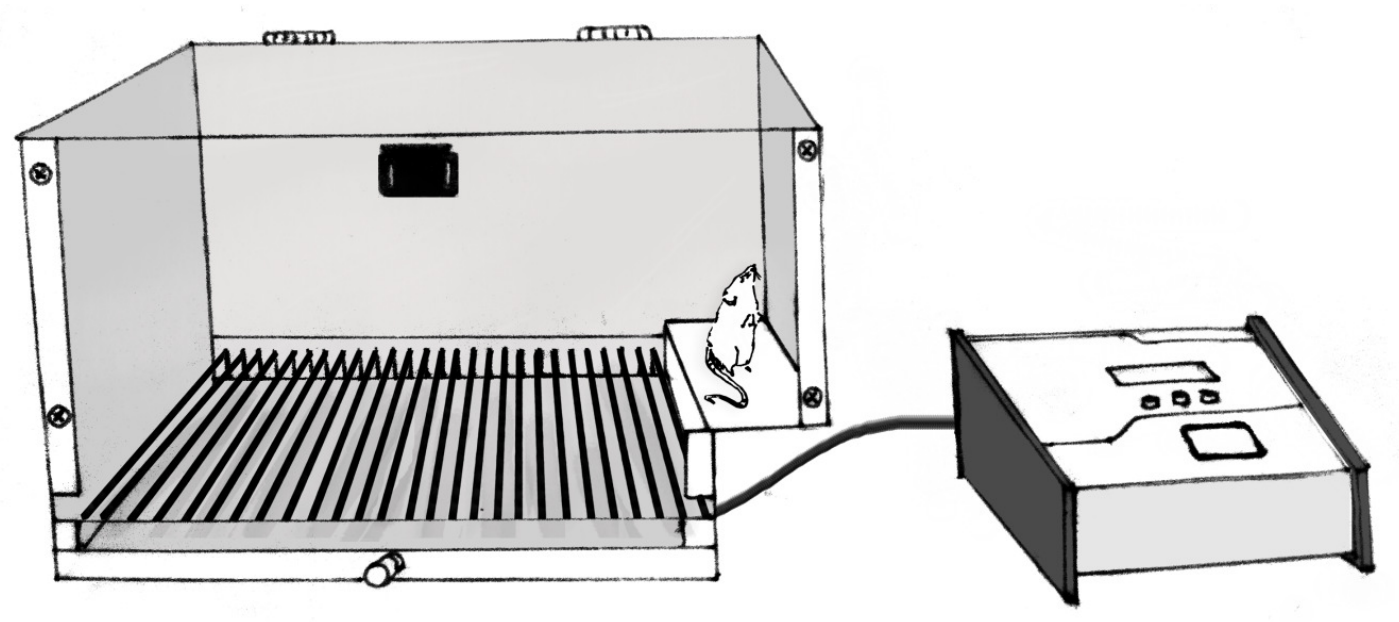

Figura 8 - Caixa de teste de Esquiva inibitória do tipo step-down utilizada para avaliar a memória de curta e longa duração em ratos durante 3 minutos.

Após a avaliação de cada animal, os aparatos sempre eram limpos com álcool $10 \%(\mathrm{v} / \mathrm{v})$ para evitar que o odor do animal recém-testado interferisse no comportamento do animal seguinte a ser testado. 


\subsubsection{Delineamento Experimental}

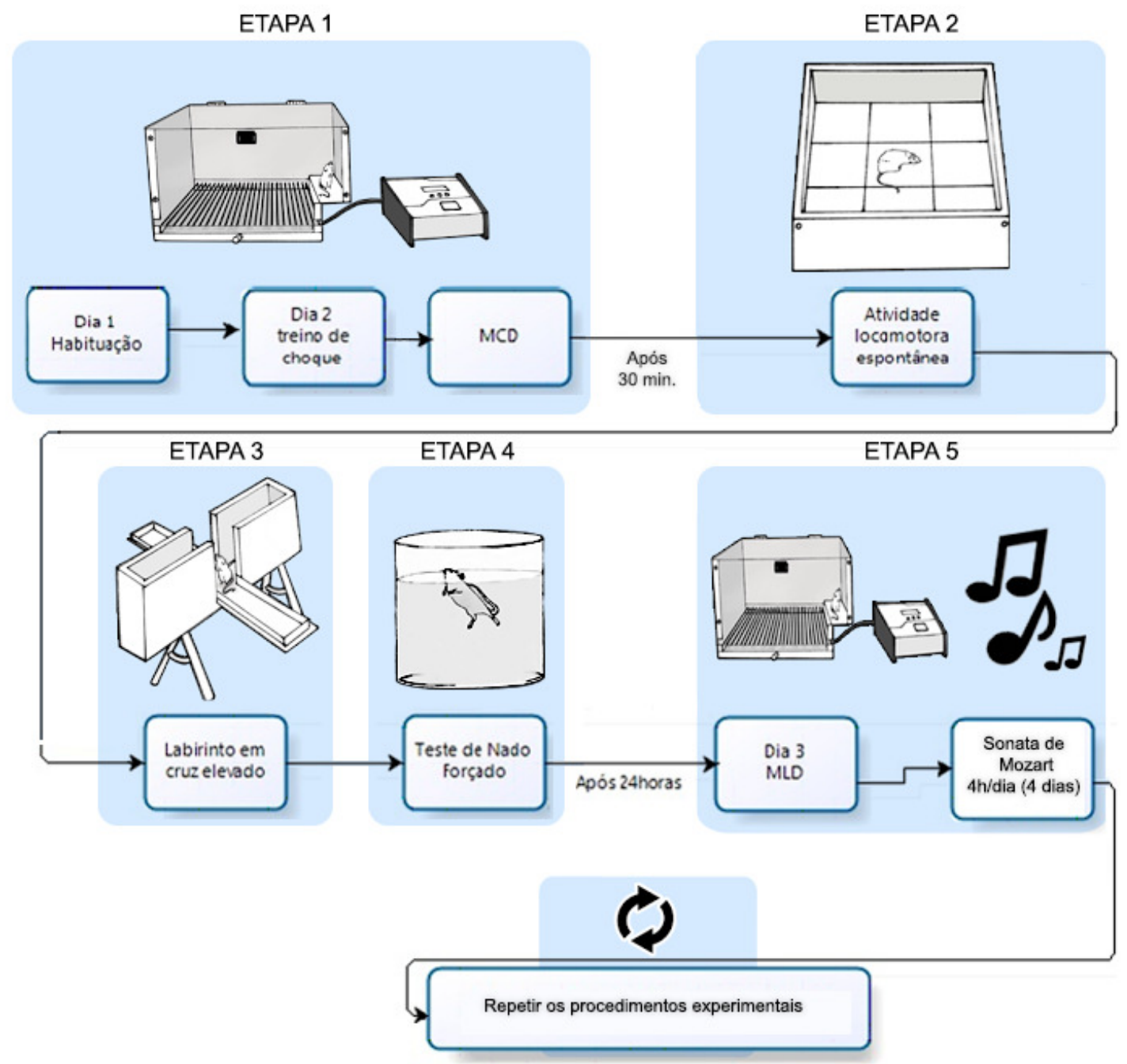

Figura 9 - Delineamento experimental: Dia 1 - habituação dos animais na caixa do teste da Esquiva Inibitória; Dia 2 - treino (choque) na caixa de teste da Esquiva Inibitória seguida da avaliação da memória de curta duração (MCD) e dos demais testes comportamentais (locomoção, ansiedade, depressão/estresse); Dia 3 - avaliação da memória de longa duração (MLD) e início da terapia da Sonata de Mozart por 4 dias, sendo 2 horas de manha e 2 horas a tarde com intervalo de 12 horas. Após essa etapa, todos os animais eram novamente avaliados nos mesmos testes. 


\subsection{ANÁLISES ESTATÍSTICAS}

Os dados utilizados foram provenientes de medidas coletadas em 10 ratos machos e 10 fêmeas Wistar. Foram coletadas medidas que visavam mensurar informações relativas à ansiedade, depressão, locomoção, MCD e MLD. As análises estatísticas dos resultados foram realizadas por meio da Análise de Variância (ANOVA) de três vias, cujas variáveis independentes foram as seguintes: idade, sexo e tratamento, onde o tratamento indicava a submissão dos ratos à música. Em relação às diferenças observadas dentre os grupos de idade, estes foram comparados entre si pelo teste post-hoc de Bonferroni para avaliar dentre quais grupos de idade as diferenças estavam presentes. A probabilidade indicativa da existência de diferença estatisticamente significante foi de $p \leq 0,05$. Os dados foram analisados utilizando o software estatístico SPSS, versão 17 e os gráficos foram gerados utilizando-se o software GraphPad Prism, versão $5.01 \AA$, 2010 (San Diego, CA). 


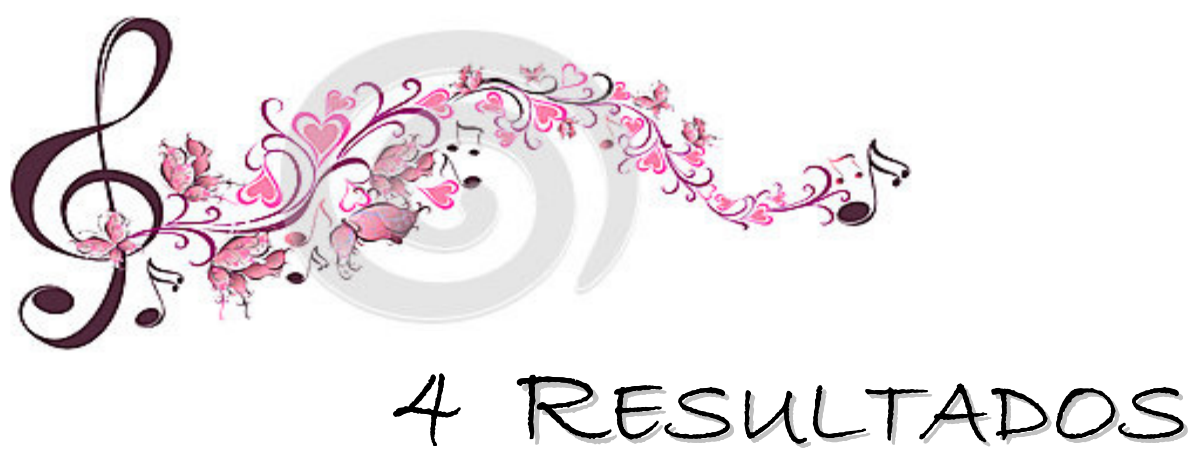




\subsection{TESTE DO CAMPO ABERTO}

Nesse teste, que analisa a quantidade de quadrantes percorridos pelos ratos, não houve diferença estatisticamente significante para 0 sexo $\left[F_{(1,159)}=0,046 ; p=0,831\right]$. Na variável tratamento, também não houve diferença significante $\left[F_{(1,159)}=0,940 ; p=0,334\right]$. Para a variável idade, houve diferença significante $\left[F_{(3,159)}=10,704 ; p<0,001\right]$. A idade está dividida em quatro grupos (ratos de 1, 2, 3 e 4 meses). Nesse caso, foi realizado o teste post hoc de Bonferroni para avaliar dentre quais grupos de idade essa diferença, relativa à locomoção, estava presente (Tabela 1).

Tabela 1 - Média dos quadrantes percorridos nas diferentes faixas etárias e comparações entre pares de idade, sendo destacadas em cinza as que foram significantes $(p \leq 0,05)$.

\begin{tabular}{|c|c|c|c|c|}
\hline $\begin{array}{c}\text { Idade (em } \\
\text { meses) }\end{array}$ & $\begin{array}{l}\text { Média de } \\
\text { quadrantes } \\
\text { percorridos }\end{array}$ & $\begin{array}{c}\text { Comparação } \\
\text { entre pares } \\
\text { de idade }\end{array}$ & $\begin{array}{l}\text { Diferença } \\
\text { média }\end{array}$ & $p$ \\
\hline \multirow{3}{*}{1} & \multirow{3}{*}{58,8} & 2 & 14,80 & 0,002 \\
\hline & & 3 & 11,33 & 0,030 \\
\hline & & 4 & 22,08 & 0,000 \\
\hline \multirow{3}{*}{2} & \multirow{3}{*}{44,0} & 1 & $-14,80$ & 0,002 \\
\hline & & 3 & $-3,47$ & 1,000 \\
\hline & & 4 & 7,27 & 0,416 \\
\hline \multirow{3}{*}{3} & \multirow{3}{*}{47,5} & 1 & $-11,33$ & 0,030 \\
\hline & & 2 & $-3,47$ & 1,000 \\
\hline & & 4 & 10,75 & 0,046 \\
\hline \multirow{3}{*}{4} & \multirow{3}{*}{36,7} & 1 & $-22,08$ & 0,000 \\
\hline & & 2 & $-7,27$ & 0,416 \\
\hline & & 3 & $-10,75$ & 0,046 \\
\hline
\end{tabular}

Notou-se que, à exceção dos pares envolvendo as interações a partir de 2, 3 e 4 meses, as demais interações apresentaram significância estatística relevante. Observou-se, com esses dados, que quanto maior as idades, menores ficaram as medidas de locomoção. Nesse caso, os ratos com quatro meses locomoveram-se significantemente menos do que nas demais idades, informações essas que aparecem na "média de quadrantes percorridos". 
Tabela 2 - Análise das interações entre as variáveis independentes

\begin{tabular}{|c|c|c|}
\hline Interação & $\mathrm{F}$ & $p$ \\
\hline Sexo * Idade & 27,549 & 0,000 \\
\hline Sexo * Tratamento & 1,709 & 0,193 \\
\hline Idade * Tratamento & 1,415 & 0,241 \\
\hline $\begin{array}{l}\text { Sexo * Idade * } \\
\text { Tratamento }\end{array}$ & 0,161 & 0,922 \\
\hline
\end{tabular}

No que refere à análise das interações das variáveis (Tabela 2), notou-se que somente a interação entre as variáveis sexo e idade apresentou significância estatística. A interação entre os fatores correspondeu à diferença de comportamento de um fator (variável sexo, por exemplo) nos diferentes níveis do outro fator (idade, por exemplo) com respeito à característica de interesse (locomoção).

No caso da interação sexo $\mathrm{x}$ idade, observou-se um padrão diferenciado para machos e fêmeas: enquanto as fêmeas tenderam a se locomover mais com a idade, os machos tenderam a diminuir. Quando se comparou as respostas aos pares em cada idade, conforme cada sexo, não se se observou qualquer influência da música em relação aos seus respectivos controles (Figura 10). 


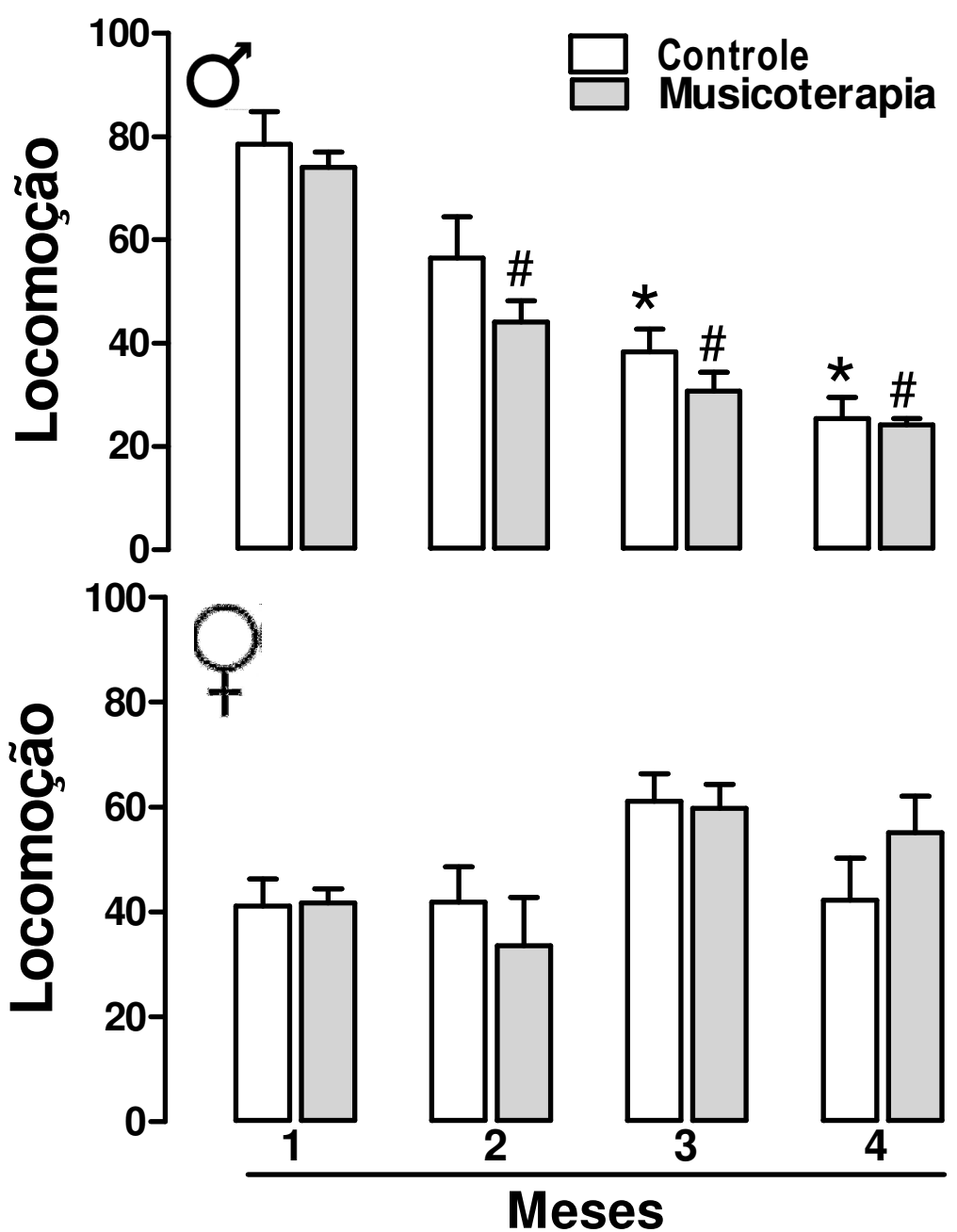

Figura 10 - Atividade locomotora de ratos machos (painel superior) e fêmeas (painel inferior) do grupo controle e do grupo que recebeu Musicoterapia, quando avaliados no Teste do campo aberto, por 5 minutos. Os resultados do controle foram sempre considerados para as avaliações que antecediam a sequência de música em cada idade. Os dados representam a média \pm epm de 10 animais/sexo. ${ }^{*} p \leq 0,05$ comparado aos animais controles com 1 mês de idade; \# $p \leq 0,05$ comparado aos resultados dos animais quando receberam a terapia da música com 1 mês de idade (ANOVA, teste de Bonferroni).

\subsection{TESTE DO LCE}

A avaliação do nível de ansiedade de ratos do grupo controle e do grupo que recebeu Musicoterapia foi verificada por meio do LCE logo após a avaliação do Teste do Campo Aberto.

\section{Percentual de entrada nos braços abertos do LCE}

Nesse teste não houve diferença estatisticamente significante para a variável sexo $\left[F_{(1,159)}=0,047 ; p=0,828\right]$. Na variável tratamento, também não houve 
diferença significante $\left[F_{(1,159)}=0,965 ; p=0,328\right]$. Para a variável idade, houve diferença significante $\left[F_{(3,159)}=22,268 ; p<0,001\right]$. $O$ teste post hoc de Bonferroni, para avaliar quais grupos de idade diferiram entre si, apresentou os seguintes resultados (Tabela 3):

Tabela 3 - Média do percentual de entrada nos braços abertos do LCE nas diferentes faixas etárias e comparações entre pares de idade, sendo destacadas em cinza as que foram significantes $(p \leq 0,05)$.

\begin{tabular}{|c|c|c|c|c|}
\hline $\begin{array}{l}\text { Idade } \\
\text { (em } \\
\text { meses) }\end{array}$ & $\begin{array}{l}\text { Entradas } \\
\text { Médias } \\
\text { (em \%) }\end{array}$ & $\begin{array}{c}\text { Comparação } \\
\text { entre pares } \\
\text { de idade }\end{array}$ & $\begin{array}{l}\text { Diferença } \\
\text { Média }\end{array}$ & $p$ \\
\hline \multirow{3}{*}{1} & \multirow{3}{*}{32,3} & 2 & 11,56 & 0,001 \\
\hline & & 3 & 14,25 & 0,000 \\
\hline & & 4 & 23,71 & 0,000 \\
\hline \multirow{3}{*}{2} & \multirow{3}{*}{20,7} & 1 & $-11,56$ & 0,001 \\
\hline & & 3 & 2,69 & 1,000 \\
\hline & & 4 & 12,15 & 0,000 \\
\hline \multirow{3}{*}{3} & \multirow{3}{*}{18,0} & 1 & $-14,25$ & 0,000 \\
\hline & & 2 & $-2,69$ & 1,000 \\
\hline & & 4 & 9,46 & 0,009 \\
\hline \multirow{3}{*}{4} & \multirow{3}{*}{8,6} & 1 & $-23,71$ & 0,000 \\
\hline & & 2 & $-12,15$ & 0,000 \\
\hline & & 3 & $-9,46$ & 0,009 \\
\hline
\end{tabular}

Notou-se que, à exceção dos pares envolvendo as interações com 2 e 3 meses, as demais interações apresentaram significância estatística relevante. Observou-se que quanto maior a idade, menos vezes o rato entrou nos braços abertos do LCE, conforme demonstrado nas "médias das entradas (em \%)"

Tabela 4 - Interação entre as variáveis independentes e sua significância $(p \leq 0,05)$.

\begin{tabular}{l|c|c}
\multicolumn{1}{c|}{ Interação } & $\mathrm{F}$ & $p$ \\
\hline Sexo * Idade & 0,214 & 0,887 \\
\hline Sexo * Tratamento & 7,310 & 0,008 \\
\hline Idade * Tratamento & 0,323 & 0,809 \\
\hline Sexo * Idade * Tratamento & 0,765 & 0,515 \\
\hline
\end{tabular}

Conforme demonstrado na Tabela 4, a análise entre as variáveis mostrou que somente a interação entre sexo e tratamento foi significante, em especial nos animais com 4 meses de idade. Nos ratos machos, a terapia com a música 
reduziu o percentual de entradas nos braço abertos do LCE, enquanto que nas fêmeas aumentou esse parâmetro (Figura 11 - painéis superiores)

\section{Percentual de tempo de permanência nos braços abertos do LCE}

Nesse teste não houve diferença estatisticamente significante para a variável sexo $\left[F_{(1,159)}=0,641 ; p=0,425\right]$. Na variável tratamento, também não houve diferença significante $\left[F_{(1,159)}=2,796 ; p=0,097\right]$, apesar do baixo valor de "p". Para a variável idade, houve diferença significante $\left[F_{(3,159)}=14,614 ; p<0,001\right]$. A idade está dividida em quatro grupos (ratos de 1, 2, 3 e 4 meses). O teste post hoc de Bonferroni, para avaliar quais grupos de idade diferiram entre si, apresentou os seguintes resultados (Tabela 5):

Tabela 5 - Média do percentual do tempo de permanência nos braços abertos do LCE nas diferentes faixas etárias e comparações entre pares de idade, sendo destacadas em cinza as que foram significantes $(p \leq 0,05)$.

\begin{tabular}{|c|c|c|c|c|}
\hline $\begin{array}{l}\text { Idade } \\
\text { (em } \\
\text { meses) }\end{array}$ & $\begin{array}{c}\text { Tempo de } \\
\text { Permanência } \\
\text { (em \%) }\end{array}$ & $\begin{array}{c}\text { Comparação } \\
\text { entre pares } \\
\text { de idade }\end{array}$ & $\begin{array}{c}\text { Diferença } \\
\text { Média }\end{array}$ & $p$ \\
\hline \multirow{3}{*}{1} & \multirow{3}{*}{18,7} & 2 & 8,46 & 0,002 \\
\hline & & 3 & 10,38 & 0,000 \\
\hline & & 4 & 14,67 & 0,000 \\
\hline \multirow{3}{*}{2} & \multirow{3}{*}{10,2} & 1 & $-8,46$ & 0,002 \\
\hline & & 3 & 1,92 & 1,000 \\
\hline & & 4 & 6,20 & 0,044 \\
\hline \multirow{3}{*}{3} & \multirow{3}{*}{8,3} & 1 & $-10,38$ & 0,000 \\
\hline & & 2 & $-1,92$ & 1,000 \\
\hline & & 4 & 4,28 & 0,372 \\
\hline \multirow{3}{*}{4} & \multirow{3}{*}{4,0} & 1 & $-14,67$ & 0,000 \\
\hline & & 2 & $-6,20$ & 0,044 \\
\hline & & 3 & $-4,28$ & 0,372 \\
\hline
\end{tabular}

Notou-se que apenas os pares "2 e 3 meses" e "3 e 4 meses" não diferiram entre si. Em geral, observou-se uma tendência de menor tempo de permanência nos braços abertos quanto maior a idade. 
Tabela 6 - Interação entre as variáveis independentes e sua significância $(p \leq 0,05)$.

\begin{tabular}{l|r|c}
\multicolumn{1}{c|}{ Interação } & \multicolumn{1}{c|}{$\mathrm{F}$} & \multicolumn{1}{c}{$p$} \\
\hline Sexo * Idade & 0,615 & 0,607 \\
\hline Sexo * Tratamento & 27,935 & 0,000 \\
\hline Idade * Tratamento & 0,842 & 0,473 \\
\hline Sexo * Idade * Tratamento & 2,372 & 0,073 \\
\hline
\end{tabular}

A única interação significativa foi entre as variáveis sexo e tratamento. Nesse caso, as fêmeas controles não alteraram suas respostas ao longo das idades. No entanto, a aplicabilidade da terapia com a música estimulou os animais a permanecerem mais tempo nos braços abertos do LCE e os ratos machos apresentaram uma diminuição, sendo que a música reduziu esse parâmetro nos animais com 1 mês de idade (Figura 11 - painéis intermediários).

\section{Frequência de entrada nos braços fechados do LCE}

Nesse teste houve diferença significante para a variável sexo $\left[F_{(1,159)}=67,616 ; \quad p<0,001\right]$. Na variável tratamento não houve diferença $\left[F_{(1,159)}=0,043 ; p=0,837\right]$. Para a variável idade, houve diferença significante $\left[F_{(3,159)}=10,955 ; p<0,001\right]$. O teste de Bonferroni, para avaliar quais grupos de idade diferiram entre si, apresentou os seguintes resultados (Tabela 7):

Tabela 7 - Média da frequência de entrada nos braços fechados do LCE nas diferentes faixas etárias e comparações entre pares de idade, sendo destacadas em cinza as que foram significantes $(p \leq 0,05)$.

\begin{tabular}{|c|c|c|c|c|}
\hline $\begin{array}{c}\text { Idade (em } \\
\text { meses) }\end{array}$ & $\begin{array}{l}\text { Entradas } \\
\text { Médias }\end{array}$ & $\begin{array}{l}\text { Comparação } \\
\text { entre pares } \\
\text { de idade }\end{array}$ & $\begin{array}{c}\text { Diferença } \\
\text { Média }\end{array}$ & $p$ \\
\hline \multirow{3}{*}{1} & \multirow{3}{*}{6,9} & 2 & $-1,33$ & 0,172 \\
\hline & & 3 & 0,48 & 1,000 \\
\hline & & 4 & 2,08 & 0,004 \\
\hline \multirow{3}{*}{2} & \multirow{3}{*}{8,2} & 1 & 1,33 & 0,172 \\
\hline & & 3 & 1,80 & 0,019 \\
\hline & & 4 & 3,40 & 0,000 \\
\hline \multirow{3}{*}{3} & \multirow{3}{*}{6,4} & 1 & $-0,48$ & 1,000 \\
\hline & & 2 & $-1,80$ & 0,019 \\
\hline & & 4 & 1,60 & 0,051 \\
\hline \multirow{3}{*}{4} & \multirow{3}{*}{4,8} & 1 & $-2,08$ & 0,004 \\
\hline & & 2 & $-3,40$ & 0,000 \\
\hline & & 3 & $-1,60$ & 0,051 \\
\hline
\end{tabular}


Observou-se que somente os pares "1 e 4 meses" e "2 e 4 meses" diferiram entre si. Houve uma diferença de número de entradas nos braços fechados entre os ratos mais novos e mais velhos.

Tabela 8 - Interação entre as variáveis independentes e sua significância $(p \leq 0,05)$.

\begin{tabular}{l|c|c}
\hline \multicolumn{1}{c|}{ Interação } & $F$ & $p$ \\
\hline Sexo * Idade & 5,681 & 0,001 \\
\hline Sexo * Tratamento & 3,670 & 0,057 \\
\hline Idade * Tratamento & 0,552 & 0,647 \\
\hline Sexo * Idade * Tratamento & 1,154 & 0,329 \\
\hline
\end{tabular}

A análise das interações evidenciou significância apenas na interação entre as variáveis sexo e idade. Aumentando a idade da fêmea, manteve-se certo padrão de entrada nos braços fechados. No caso dos machos, a diminuição desse número de entradas foi mais evidente (Figura 11 - painéis inferiores). 


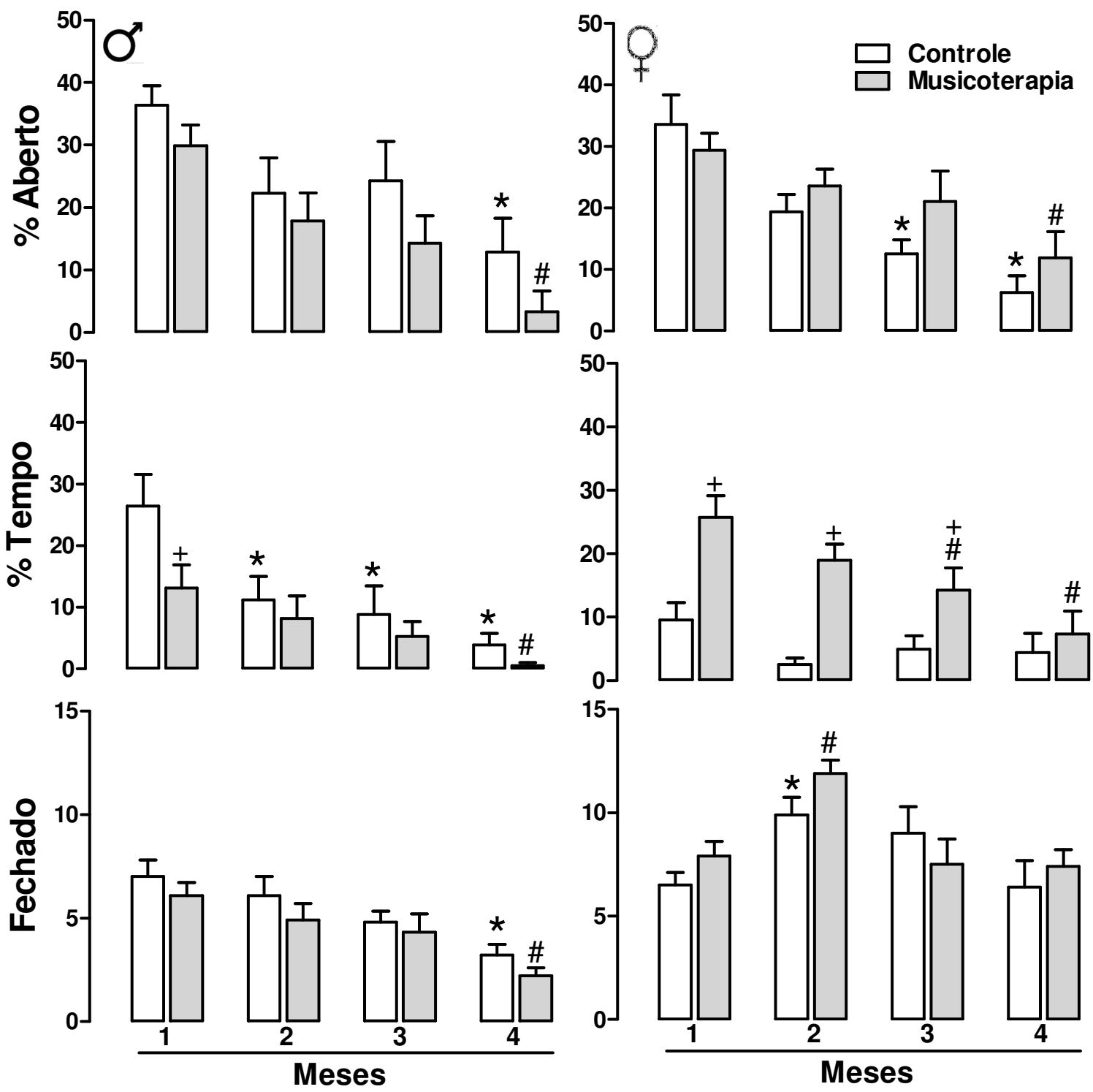

Figura 11 - Avaliação do comportamento de ansiedade de ratos machos (painéis à esquerda) e fêmeas (painéis á direita) do grupo controle e do grupo que recebeu Musicoterapia, avaliados no teste do LCE por 5 minutos. Os resultados do controle foram sempre considerados para as avaliações que antecediam a sequência de música em cada idade. A) \% Aberto - representa a porcentagem de entradas nos braços abertos do LCE; B) \%Tempo - representa a porcentagem de tempo de permanência nos braços abertos do LCE; C) Fechado - representa a frequência de entrada nos braços fechados do LCE. ${ }^{*} \mathrm{p} \leq 0,05$ comparado aos animais do grupo controle com 1 mês de idade; \#p $\leq 0,05$ comparado aos animais que receberam música com 1 mês de idade; $+p \leq 0,05$ comparado aos respectivos grupos controles intragrupos (ANOVA, Teste de Bonferroni).

\subsection{TESTE DO NADO FORÇADO}

Este teste permitiu avaliar o comportamento sugestivo de depressão/estresse a partir da imobilidade dos animais quando colocados no tanque de água. Não houve diferença estatisticamente significante para a variável 
sexo $\left[F_{(1,159)}=0,028 ; p<0,868\right]$. Na variável tratamento houve diferença significante $\left[F_{(1,159)}=8,041 ; p=0,005\right]$, Para a variável idade, houve diferença significante $\left[F_{(3,159)}=17,184 ; p<0,001\right]$. O teste post hoc de Bonferroni, para avaliar quais grupos de idade diferiram entre si, apresentou os seguintes resultados (Tabela 9):

Tabela 9 - Tempo médio de imobilidade nas diferentes faixas etárias e comparações entre pares de idade, sendo destacados em cinza os que foram significantes $(p \leq 0,05)$.

\begin{tabular}{|c|c|c|c|c|}
\hline $\begin{array}{c}\text { Idade (em } \\
\text { meses) }\end{array}$ & $\begin{array}{c}\text { Tempo } \\
\text { Médio de } \\
\text { Imobilidade }\end{array}$ & $\begin{array}{l}\text { Comparação } \\
\text { entre pares } \\
\text { de idade }\end{array}$ & $\begin{array}{c}\text { Diferença } \\
\text { Média }\end{array}$ & $p$ \\
\hline \multirow{3}{*}{1} & \multirow{3}{*}{65,7} & 2 & $-46,45$ & 0,000 \\
\hline & & 3 & $-33,15$ & 0,000 \\
\hline & & 4 & $-39,00$ & 0,000 \\
\hline \multirow{3}{*}{2} & \multirow{3}{*}{112,2} & 1 & 46,45 & 0,000 \\
\hline & & 3 & 13,30 & 0,355 \\
\hline & & 4 & 7,45 & 1,000 \\
\hline \multirow{3}{*}{3} & \multirow{3}{*}{98,9} & 1 & 33,15 & 0,000 \\
\hline & & 2 & $-13,30$ & 0,355 \\
\hline & & 4 & $-5,85$ & 1,000 \\
\hline \multirow{3}{*}{4} & \multirow{3}{*}{104,7} & 1 & 39,00 & 0,000 \\
\hline & & 2 & $-7,45$ & 1,000 \\
\hline & & 3 & 5,85 & 1,000 \\
\hline
\end{tabular}

$\mathrm{Na}$ tabela acima, notou-se que apenas os ratos com um mês de idade diferiram significantemente das demais faixas etárias. Notou-se, ainda, que a partir do primeiro mês todos tiveram um aumento significativo do tempo de imobilidade.

Tabela 10 - Interação entre as variáveis independentes e sua significância $(p \leq 0,05)$.

\begin{tabular}{l|r|c}
\hline \multicolumn{1}{c|}{ Interação } & \multicolumn{1}{c|}{$\mathrm{F}$} & \multicolumn{1}{c}{$p$} \\
\hline Sexo * Idade & 14,240 & 0,000 \\
\hline Sexo * Tratamento & 10,206 & 0,002 \\
\hline Idade * Tratamento & 2,487 & 0,063 \\
\hline Sexo * Idade * Tratamento & 15,846 & 0,000 \\
\hline
\end{tabular}


A análise das interações (Tabela 10) mostrou que a relação entre as variáveis sexo e idade foi significativa. Quanto mais velho os ratos, independente do sexo, maior foi o tempo de imobilidade. Para as fêmeas com 1 mês de idade, o tempo médio de imobilidade aumentou com a música, enquanto que o machos com a mesma idade houve uma redução nesse parâmetro (Figura 12).

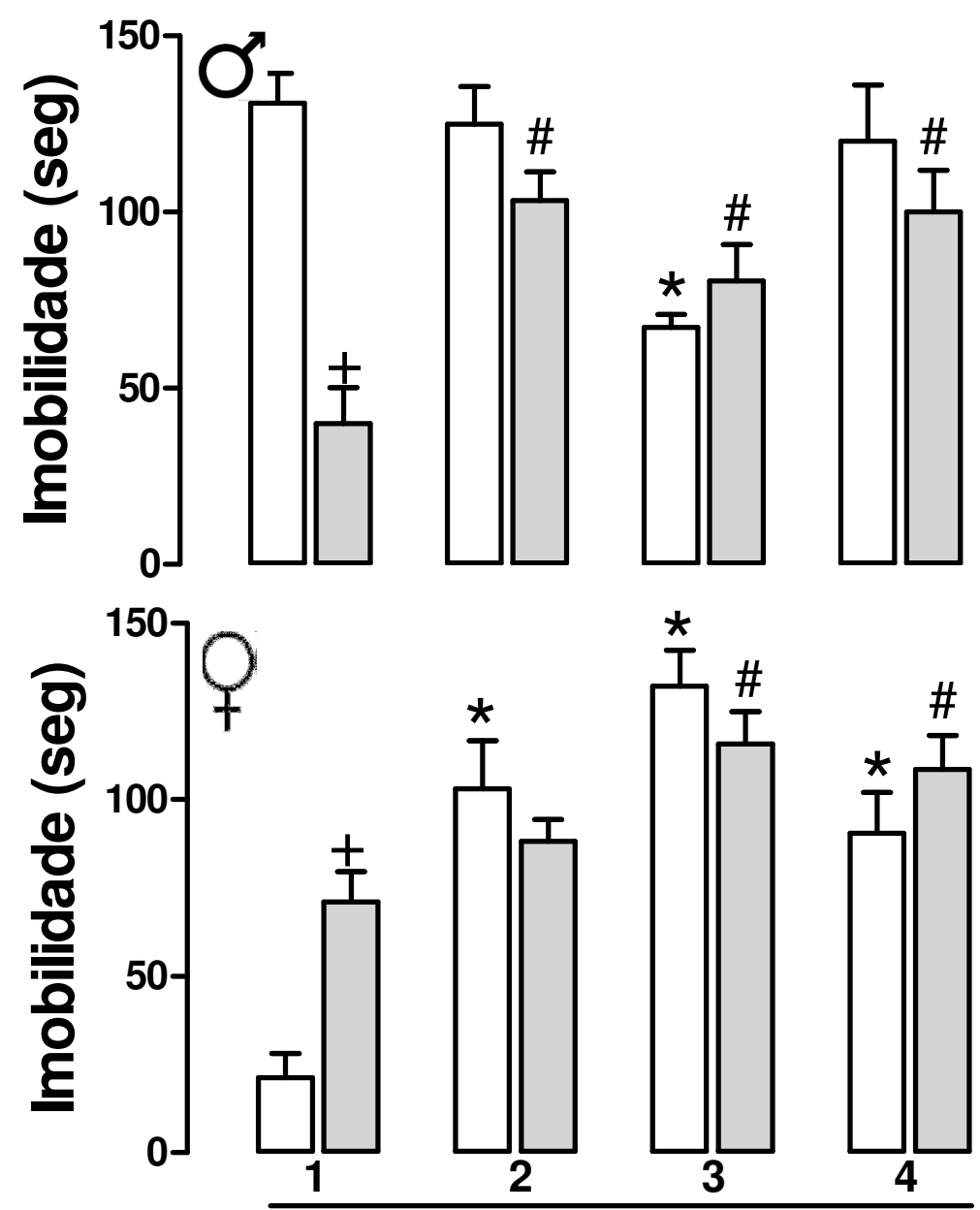

Meses

Figura 12 - Influência da Musicoterapia em ratos machos (painel superior) e fêmeas (painel inferior) avaliados quanto ao tempo de imobilidade no teste do Nado forçado, por um período de 3 minutos. Os resultados do controle foram sempre considerados para as avaliações que antecediam a sequência de música em cada idade. ${ }^{*} p \leq 0,05$ comparado aos animais do grupo controle com 1 mês de idade; $\# p \leq 0,05$ comparado aos animais que receberam música com 1 mês de idade; $+p \leq 0,05$ comparado aos respectivos grupos controles intragrupos (ANOVA, Teste de Bonferroni).

Em relação ao comportamento sugestivo de depressão/estresse, notou-se na figura 12 que a presença da música só influenciou, de maneira estatisticamente significante, na imobilidade dos ratos machos e fêmeas com 1 mês de idade, sendo que os machos ficaram mais estressados após a música, enquanto que as fêmeas ficaram mais imóveis. 


\subsection{TESTE DA ESQUIVA INIBITÓRIA DO TIPO STEP DOWN}

\section{Memória de Curto Prazo}

Nesse teste não houve diferença estatisticamente significante para a variável sexo $\left[F_{(1,159)}=0,178 ; p=0,673\right]$. Também não houve significância para a variável tratamento $\left[F_{(1,159)}=2,628 ; p=0,107\right]$. Para a variável idade, houve diferença significante $\left[F_{(3,159)}=6,778 ; p<0,001\right]$. O teste post hoc de Bonferroni, para avaliar quais grupos de idade diferiram entre si, apresentou os seguintes resultados (Tabela 11):

Tabela 11 - Tempo médio de descida da plataforma nas diferentes faixas etárias e comparações entre pares de idade, sendo destacados em cinza os que foram significantes $(p \leq 0,05)$.

\begin{tabular}{|c|c|c|c|c|}
\hline $\begin{array}{c}\text { Idade (em } \\
\text { meses) }\end{array}$ & $\begin{array}{c}\text { Tempo } \\
\text { Médio } \\
\text { de } \\
\text { Descida }\end{array}$ & $\begin{array}{c}\text { Comparação } \\
\text { entre pares } \\
\text { de idade }\end{array}$ & $\begin{array}{c}\text { Diferença } \\
\text { Média }\end{array}$ & $p$ \\
\hline \multirow{3}{*}{1} & \multirow{3}{*}{46,2} & 2 & $-25,90$ & 0,353 \\
\hline & & 3 & $-44,27$ & 0,008 \\
\hline & & 4 & $-57,85$ & 0,000 \\
\hline \multirow{3}{*}{2} & \multirow{3}{*}{72,1} & 1 & 25,90 & 0,353 \\
\hline & & 3 & $-18,37$ & 1,000 \\
\hline & & 4 & $-31,95$ & 0,121 \\
\hline \multirow{3}{*}{3} & \multirow{3}{*}{90,5} & 1 & 44,27 & 0,008 \\
\hline & & 2 & 18,37 & 1,000 \\
\hline & & 4 & $-13,58$ & 1,000 \\
\hline \multirow{3}{*}{4} & \multirow{3}{*}{104,1} & 1 & 57,85 & 0,000 \\
\hline & & 2 & 31,95 & 0,121 \\
\hline & & 3 & 13,58 & 1,000 \\
\hline
\end{tabular}

Notou-se que o rato com um mês de idade diferiu significantemente de todas as outras idades, visto que quanto mais o rato ia atingindo uma maior idade, maior era o tempo que ele demorava para descer da plataforma.

Tabela 12 - Interação entre as variáveis independentes e sua significância $(p \leq 0,05)$.

\begin{tabular}{l|c|c}
\hline \multicolumn{1}{c|}{ Interação } & $\mathrm{F}$ & $p$ \\
\hline Sexo ${ }^{*}$ Idade & 4,895 & 0,003 \\
\hline Sexo Tratamento & 0,660 & 0,418 \\
\hline Idade * Tratamento & 1,087 & 0,357 \\
\hline Sexo * Idade * Tratamento & 0,985 & 0,402 \\
\hline
\end{tabular}


Observou-se pela Tabela 12 que apenas a interação entre as variáveis sexo e idade apresentou diferença significativa. De uma maneira geral, conforme as idades iam avançando, os animais se mantinham por um período maior na plataforma do aparato (Figura 13).

\section{Memória de Longo Prazo}

Nesse teste não houve diferença estatisticamente significante para nenhuma variável: para a variável sexo $\left[\mathrm{F}_{(1,159)}=0,055 ; \mathrm{p}=0,815\right]$, para a variável tratamento $\left[F_{(1,159)}=0,124 ; p=0,726\right]$, para a variável idade $\left[F_{(3,159)}=1,547 ; p=0,205\right]$. As interações também não se mostraram significantes, conforme tabela 13 a seguir.

Tabela 13 - Interação entre as variáveis independentes e sua significância $(p \leq 0,05)$.

\begin{tabular}{l|c|c}
\hline \multicolumn{1}{c|}{ Interação } & $F$ & $p$ \\
\hline Sexo * Idade & 1,485 & 0,221 \\
\hline Sexo * Tratamento & 0,868 & 0,353 \\
\hline Idade * Tratamento & 0,740 & 0,530 \\
\hline Sexo * Idade * Tratamento & 0,336 & 0,799 \\
\hline
\end{tabular}

Por meio da figura 13 é possível verificar que a permanência na plataforma foi gradual conforme a sequência de avaliações em cada idade, sem diferenças estatísticas relevantes. 


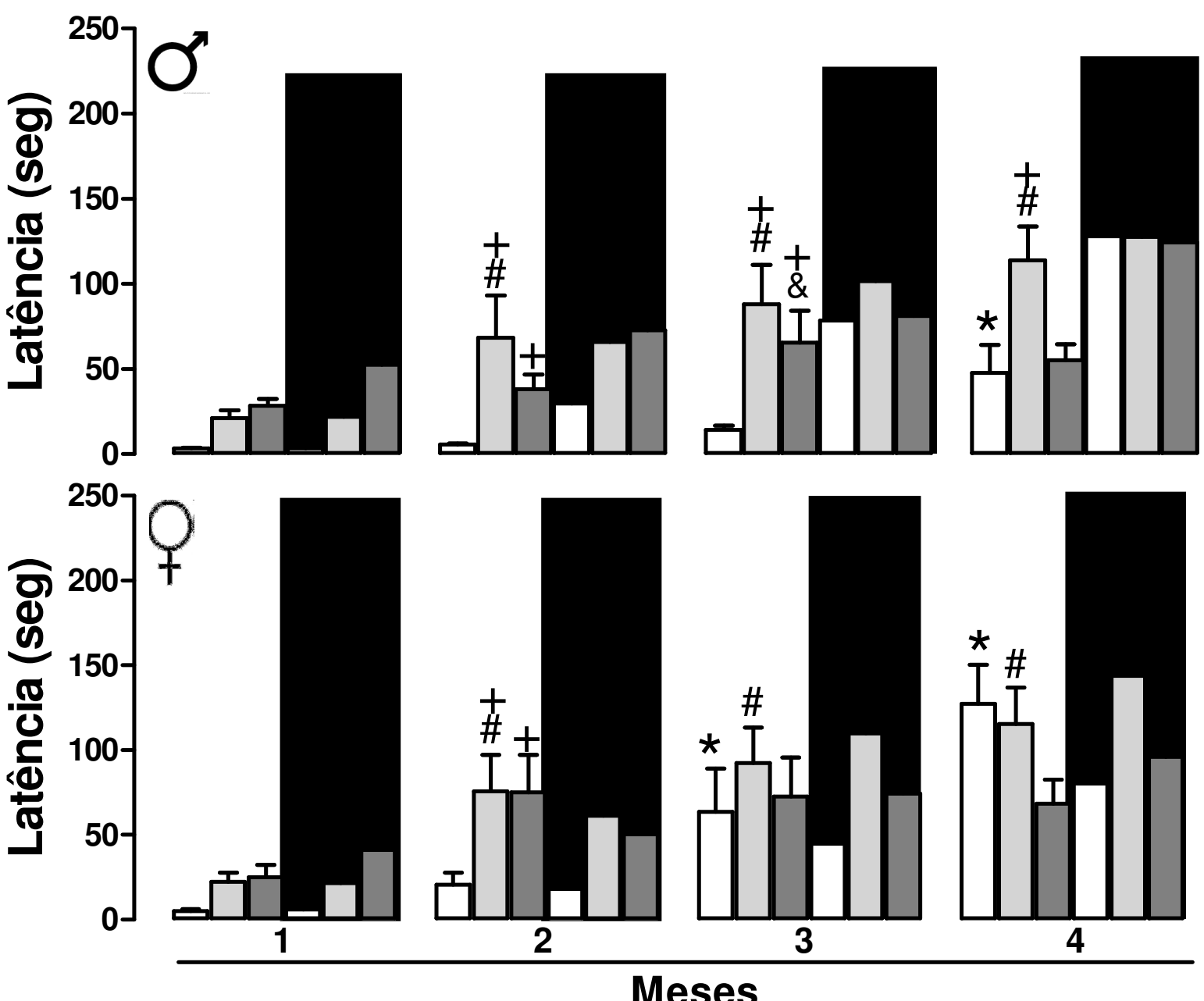

Figura 13 - Influência da Musicoterapia no treino (choque), memória de curta e longa duração em ratos machos (painel superior) e fêmeas (painel inferior) avaliados quanto ao tempo para descer da plataforma no teste de Esquiva Inibitória, por um período de 3 minutos. Os resultados do controle foram sempre considerados para as avaliações que antecediam a sequência de música em cada idade. * $p \leq 0,05$ comparado aos animais do grupo controle com 1 mês de idade; $\# p \leq 0,05$ comparado aos resultados da memória de curta duração dos animais com 1 mês de idade; \&p $\leq 0,05$ comparado aos resultados da memória de longa duração dos animais com 1 mês de idade; "a" $p \leq 0,05$ comparado aos resultados dos animais do grupo controle que recebeu a terapia da música com 1 mês de idade; "b" $p \leq 0,05$ comparado aos resultados da memória de curta duração dos animais que receberam a terapia da música com 1 mês de idade; "c" $\leq \leq 0,05$ comparado aos resultados da memória de longa duração dos animais que receberam a terapia da música com 1 mês de idade; "+" $\leq \leq 0,05$ comparado com os respectivos grupos controles intragrupos. Barras brancas= treino (choque); Barras cinzas claras= memória de curta duração; Barras cinzas escuras: memória de longa duração.As ilustrações da notas musicais representam os resultados dos animais que receberam a sessão da Sonata de Mozart. 


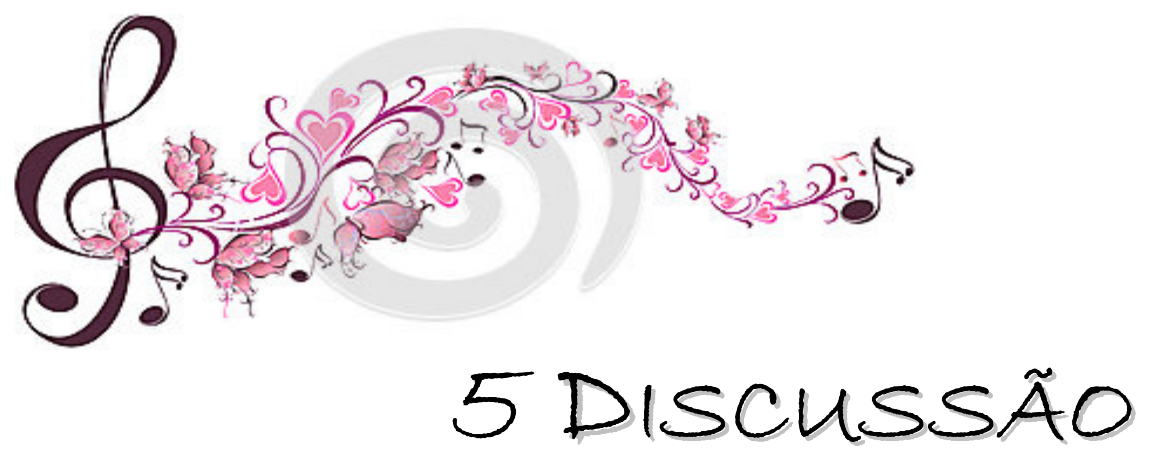


O efeito modulador da Musicoterapia parece interferir, de forma positiva, no comportamento de animais submetidos à Sonata de Mozart, principalmente quanto à variável idade, quando avaliados em diferentes faixas etárias. Não se descarta, entretanto, a possibilidade de parte desses resultados ser em decorrência de um processo adaptativo em decorrência das repetições dos testes ocorridos ao longo de todas as etapas de desenvolvimento dos animais. Dessa maneira, essas repetições podem ter gerado uma espécie de "memória" envolvendo a retenção das informações iniciada quando os animais foram testados com um 1 mês de idade e retestados com 2, 3 e 4 meses.

No que diz respeito aos aspectos comportamentais, as respostas observadas podem ter sido decorrentes do fato de que a música induz a regulação do ritmo respiratório, relaxamento da rigidez muscular, diminuição da frequência cardíaca e pressão arterial, pela formação de uma atmosfera confortável, e alívio de tensão por aumentar as ondas alfa no cérebro. Por conta desta intervenção, reduz os índices de depressão e ansiedade, e ajuda nos processos de reabilitação (KIM et al., 2011). Além disso, ela também tem sido usada para a cura de doenças físicas e mentais. Uma breve exposição à Sonata de Mozart para dois Pianos em ré maior, K.448 (Mozart K.448), produziu aumento no raciocínio espaço temporal, o chamado "efeito Mozart" e reduziu a taxa de recorrência de convulsão e de descargas epileptiformes (LIN et al., 2014).

Na presente pesquisa, durante a avaliação isolada das variáveis testadas no LCE, relacionadas tanto ao percentual de entradas quanto ao tempo de permanência nos braços abertos, não houve diferença estatisticamente significante para a variável sexo e nem para a variável tratamento, somente para a idade, dividida em quatro grupos (ratos de 1, 2, 3 e 4 meses). Na média do percentual de entradas nos braços abertos do LCE nas diferentes faixas etárias e comparação entre pares de idade, à exceção dos ratos com 2 e 3 meses, os demais pares de idade diferiam entre si, ou seja, quanto maior a idade, menos vezes o rato entrou nos braços abertos do LCE. Na média do percentual de tempo de permanência nos braços abertos do LCE nas diferentas faixas etárias e comparação entre pares de idade notou-se que apenas os pares "2 e 3 meses" e "3 e 4 meses" não diferiram entre si. Em geral, observou-se uma tendência de 
menor tempo de permanência nos braços abertos quanto maior era a idade, demonstrado claramente nos ratos machos.

A interação entre as variáveis independentes e sua significância no teste do LCE (percentual de entrada e tempo de permanência nos braços abertos) mostrou que somente a interação entre sexo e tratamento foi significante, ou seja, a presença da música só influenciou no percentual de tempo de permanência nos braços abertos do LCE dos machos com 1 mês de idade e das fêmeas com 1, 2 e 3 meses, caracterizando efeitos sugestivos de resposta ansiogênica e ansiolítica, respectivamente.

É bem sabido que estes tipos de roedores têm maior preferência por ambientes fechados e escuros, representando, até certo ponto, proteção quando comparados aos ambientes abertos e claros (HANDLEY e MITHANI, 1984). Os resultados aqui obtidos mostraram que na frequência de entrada nos braços fechados do LCE houve diferença estatisticamente significante para a variável sexo, sendo que os machos frequentaram os braços fechados menos vezes que as fêmeas. Houve diferença significante para a variável idade, mas não a variável tratamento. Na média da frequência de entrada nos braços fechados do LCE, nas diferentes faixas etárias e comparação entre pares de idade, foram significantes somente nos pares "1 e 4 meses" e "2 e 4 meses" . A diferença foi reduzida em relação ao número de entradas nos braços fechados entre os ratos mais novos e mais velhos. A análise das interações entre as variáveis independentes evidenciou significância apenas na interação entre as variáveis sexo e idade. Aumentando a idade da fêmea, manteve-se certo padrão de entrada nos braços fechados, entretanto no caso dos machos, a diminuição desse número de entradas foi mais evidente, do primeiro mês para o quarto mês.

Os resultados observados previamente pareceram ser especificos de atividade ansiogênica ou ansiolítica visto que, além de não ter interferido na frequência de entrada dos animais dos braços fechados do LCE na maior parte das avaliações, também não interferiu na locomoção dos animais no teste do campo aberto, quando essas análises foram feitas aos pares de avaliações em cada idade. Na média dos quadrantes percorridos nas diferentes faixas etárias e comparação entre pares de idade observou-se nos machos que, quanto mais 
aumentava a idade, menor ficavam as medidas de locomoção dos ratos. Nesse caso, aqueles que atingiram quatro meses locomoveram-se significantemente menos do que nas demais idades. Na interação entre as variáveis idade e tratamento não houve significância estatística. No caso da interação sexo x idade, observou-se um padrão diferenciado para machos e fêmeas: enquanto as fêmeas tenderam a se locomover mais com a idade, os machos tenderam a diminuir. Para as variáveis sexo e tratamento, observou-se também que as fêmeas se locomoveram mais após o tratamento, em relação aos machos.

Esses dados corroboram com os resultados obtidos por Imhof et al. (1993), que compararam o desempenho de ratos Wistar, machos e fêmeas em diferentes idades (45, 60, 90, 120 e 150 dias), no teste do LCE. Até 60 dias, os animais de ambos os sexos, exibiram um elevado número de entradas e tempo gasto sobre os braços abertos (50\% ou acima). Aos 120 dias ou mais, os ratos de ambos os sexos exibiram uma redução no número de entradas e no tempo gasto nos braços abertos (abaixo de 50\%). Dentro da faixa de 60 e 120 dias, houve diferenças sexuais estatisticamente significantes. Com 90 dias, os machos apresentaram uma mudança acentuada do desempenho no LCE, enquanto que nas fêmeas o mesmo ocorreu com cerca de 120 dias. Estes resultados sugeriram uma diferença ontogenética nesses tipos de roedores e, além disso, destacaram a importância de controlar cuidadosamente a idade do animal em estudos usando o LCE.

Comportamentos preferenciais são frequentemente estabelecidos durante a infância, mas os mecanismos de circuitos neurais subjacentes permanecem desconhecidos. Pesquisa recente mostrou que a adaptação de uma análise de comportamento de nidificação confirmou a existência de um "período crítico" no desenvolvimento da preferência musical em camundongos C57BL/6. A exposição prematura à música, entre 15 a 24 dias após o nascimento, reverteu este tipo de comportamento. A imagem de expressão cFos, revelou uma ativação neuronal proeminente em resposta à música na qual os animais foram expostos. Foi observado que este aumento ocorreu apenas sob condição de plasticidade no córtex pré-frontal medial pré-límbico e infra-límbico. Não foram observadas mudanças de comportamento, nem a ativação seletiva medial do córtex préfrontal em resposta à exposição ao tom puro, indicando um efeito específico da 
música. Os cruzamentos de campo aberto foram aumentados, concomitantemente com mudanças na preferência musical, sugerindo um potencial efeito ansiolítico. Assim, a música pode oferecer tanto uma janela única para o estado emocional dos camundongos, quanto também um ensaio potencialmente eficiente para "freios" na plasticidade de período crítico, comum às áreas sensoriais e de ordem superior do cérebro (YANG at al., 2012).

Em complemento ao processamento dessas informações, estudos revelaram que a música está intimamente associada com hormônios que regulam a emoção e o comportamento humano, especialmente esteróides, incluindo os sexuais. Existe, por exemplo, uma correlação entre habilidade espacial ou habilidade musical e os níveis de testosterona e cortisol (FUKUI et al., 2012). Estudos também revelaram que a música tem efeitos neuroquímicos que podem melhorar o sistema imunológico, isto porque algumas podem elevar a produção de anticorpos, Imunoglobulina $A$ e de leucócitos, podendo refletir na capacidade de regular o humor e reduzir a ansiedade e estresse (BENENZON, 1988; CHOI et al., 2008). Várias abordagens não farmacológicas são usadas para tratar estas manifestações e muitos estudos examinaram os efeitos de intervenção musical como uma abordagem de tratamento (SAKAMOTO, 2013). Os dois importantes marcadores desses tipos de manifestações clínicas regulados pelo eixo hipotálamo-hipófise-adrenal, a Beta-endorfina e os níveis de cortisol são alterados com intervenção da música (HEGDE, 2014). Em nossos estudos não foram avaliados os níveis hormonais e nem de neurotransmissores para se certificar dessa interferência nas respostas observadas.

Um estudo investigou a ontogenia do comportamento similar ao de ansiedade em ratos machos e fêmeas, da adolescência à idade adulta, por meio de filmagem, em um ambiente novo potencialmente ameaçador. Foi examinado se o comportamento similar ao de ansiedade em ratos aumentava, diminuia ou permanecia estável durante a transição da adolescência à idade adulta, no Teste do Campo aberto e LCE. Observou-se que os roedores fêmeas adultos se locomoviam mais no Campo aberto, e passavam mais tempo nos braços abertos do LCE, do que os machos adultos. Diferenças de gênero no desempenho destas tarefas podem estar relacionadas às diferenças sexuais na motivação exploratória 
ou na capacidade de aprendizagem espacial (LYNN e BROWN, 2010). Estes dados estão de acordo com o nosso estudo.

Um estudo piloto foi realizado para investigar os efeitos da intervenção da música nos sintomas psicológicos em pacientes psiquiátricos. Houve significantes melhorias na severidade dos sintomas após 15 sessões de música quando o dados foram comparados aos dos pacientes do grupo controle. Este resultado está em consonância com dados anteriores, que mostraram que a intervenção da música é benéfica para reduzir a depressão, ansiedade e outros sintomas psicológicos. A provável justificativa para estes resultados deve-se ao fato de que a intervenção musical resulta em ativação da rede neural, levando a ativação das diferentes regiões do cérebro se executada regularmente. Estes efeitos também produzem melhora física e psicológica, trazendo benefícios sobre estresse, ansiedade e alterações do humor ( $\mathrm{CHOl}$ et al., 2008).

De acordo com a literatura, a análise etiológica descritiva realizada em um estudo, mostrou o nado como um dos primeiros comportamentos apresentados pelos ratos na sessão de testes do Nado Forçado. A frequência e a duração da imobilidade ou nado aumentaram ao longo da sessão de teste. A postura de imobilidade é interpretada como uma falha no comportamento dirigido à fuga (estado comportamental de desespero) ou o desenvolvimento de um comportamento passivo de lidar com o estímulo estressante. O desespero comportamental é impedido pelo tratamento antidepressivo. A instalação gradual de imobilidade e do nado é um dos fatores que sugere que os últimos minutos da sessão de testes são essenciais para a instalação (ou não) do desespero comportamental e, são, portanto, importantes para avaliar efeitos antidepressivos de drogas (OLIVEIRA et al., 2005).

A análise Markoviana ainda dentro da pesquisa de Oliveira et al. (2005), revelou que as transições do e para o nado foram os comportamentos mais frequentemente observados. Seria um resultado esperado, uma vez que na água, nadar é um comportamento adequado apresentado pelo animal, a fim de evitar o afogamento. A forte interligação entre a ocorrência de episódios de nado e imobilidade pode refletir concomitantemente o aumento das contagens destas variáveis ao longo do teste. As transições da ou para a imobilidade, mesmo 
menos frequentes do que as que provêm ou levam ao nado, ligou a postura passiva a todos os elementos da cadeia comportamental.

Esse padrão também pode ser esperado no referido teste, uma vez que o animal tende a assumir uma postura de imobilidade (desespero comportamental) depois de uma sessão de tensão anterior. É possível que a imobilidade atue como uma estratégia de conservação de energia, permitindo que o animal descanse do comportamento dirigido a fuga do início do teste (escalada) e proporcione condições para a execução de um comportamento ativo posterior suficiente para a sobrevivência (LUCENA et al., 2010).

$\mathrm{Na}$ presente pesquisa, a análise das interações entre as variáveis independentes e sua significância mostrou que a relação entre as variáveis sexo e idade foi significativa. Quanto mais velho os ratos, independente do sexo, maior foi o tempo de imobilidade. Porém, entre o primeiro e o quarto mês essa diferença foi maior entre as fêmeas do que dentre os machos. A relação entre as variáveis sexo e tratamento foi diferente: para as fêmeas, o tempo médio de imobilidade aumentou de forma significativa após a música. Já com os machos, observou-se uma diminuição do tempo de imobilidade, quando considerada a idade de 1 mês.

Além desses aspectos até então abordados, observou-se nas últimas décadas, um crescente corpo de evidências no uso de intervenção musical em ambiente clínico, principalmente em relação ao canto, audição musical, improvisação e outras atividades musicais, melhoraram a socialização e a cognição, o funcionamento emocional e neuromotor. Esta intervenção deveu-se ao fato, principalmente, do envolvimento de uma variedade de áreas do cérebro associadas à emoção, motivação, cognição e funções motoras (RAGLIO et al., 2015).

No teste da Esquiva Inibitória do tipo Step Down, na avaliação da memória de curto prazo não houve diferença estatisticamente significante para a variável sexo nem para tratamento, somente para a variável idade. O rato com um mês de idade diferiu significantemente de todas as outras idades. Observou-se que quanto mais o rato atingia idades mais avançadas, maior era o tempo que ele demora a descer da plataforma, sugerindo um possível aumento de sua memória. 
No entanto, devido ao desenho experimental, não se descarta que este resultado deva-se ao fato de que os mesmos procedimentos experimentais que ocorreram com 1 mês terem sido novamente repetidos quando os animais atingiram 2,3 e 4 meses de idade, uma vez que não se observou diferença estatítica nem mesmo para o controles. $\mathrm{Na}$ interação entre as variáveis apenas sexo e idade apresentaram significância. As fêmeas com um mês de idade demoraram menos tempo para descer da plataforma do que as com quatro meses. Com os machos, o padrão foi bem mais regular, apesar de ter tido um pequeno aumento. Já na memória de longo prazo não houve diferença estatisticamente significante para nenhuma variável (sexo, tratamento e idade). As interações também não se mostraram significantes.

Disfunção de memória é um sintoma chave de demência relacionada à idade. Apesar de recentes estudos sugerirem efeitos positivos da estimulação elétrica para realce da memória, seus alvos em potencial permanecem em grande parte desconhecidos. A hipótese recente é que a estimulação profunda do cérebro, direcionada para o córtex pré-frontal ventromedial reforçaria as funções de memória em um modelo experimental com rato. Os resultados mostraram que a estimulação aguda reforça a MCD, mas não a de MLD na tarefa de reconhecimento de um novo elemento. Curiosamente, após a estimulação crônica de alta frequência, ambas as memórias foram melhoradas no teste de reconhecimento do novo elemento (LIU et al., 2015).

A aplicabilidade terapêutica da música ganhou uma grande importância nos últimos anos no que diz respeito aos aspectos cognitivos, apesar de que muitas revisões musicoterápicas encontraram efeitos benéficos não somente no comportamento, mas também na interação social da doença de Alzheimer, com efeitos inconsistentes na cognição. O objetivo desse estudo foi avaliar o efeito coadjuvante em longo prazo da Musicoterapia em pacientes sob tratamento farmacológico. Casos leves da doença foram consecutivamente recrutados e voluntariamente separados em um grupo de Musicoterapia ou grupo controle por 6 meses. As avaliações dos resultados incluíram habilidades cognitivas, exame de estado mental e classificação da demência clínica. As intervenções usadas foram a Sonata de Mozart (KV 448) e Canon de Pachelbel, ouvidas com fones de 
ouvido durante 30 minutos, diariamente pela manhã e antes de dormir, respectivamente. Diferenças ajustadas de exame de estado mental depois de 6 meses no grupo Musicoterapia foram ligeiramente menores do que o grupo controle, porém sem significância estatística. Em uma análise adicional dos domínios cognitivos, a diferença no grupo Musicoterapia foi significativamente melhor do que o grupo controle (LI et al., 2015).

Em complementaridade às informações previas cabe-se destacar que, por ouvir música, pacientes com Doença de Alzheimer mostraram melhoras da memória autobiográfica e na memória das letras. A eficácia da musicoterapia na demência tem sido demonstrada em recentes revisões sistemáticas. Em idosos saudáveis, as intervenções de treinamento cognitivo que oferecem prática em memória, atenção, coordenação motora fina e visual e processamento auditivo têm sido associados com ganhos cognitivos. Há achados de que músicos idosos apresentaram maior e melhor memória auditiva do que os não músicos. Além disso, observou-se também indícios de que a formação musical pode reduzir o impacto de quedas relacionadas com a idade, ou seja, a Musicoterapia pode ser útil para manter função cognitiva em idosos normais e em pacientes com demência (SATOH et al., 2014).

O impacto da Musicoterapia no tratamento de pacientes com demência de Alzheimer mostra, ainda, que a música altera os diferentes componentes da doença por meio dos impactos sensoriais, cognitivos, emocionais, comportamentais e sociais e os vários componentes da evolução global desta doença. Também é útil para diminuir a medicação administrada, reduzir significativamente a ansiedade, a depressão e agressividade dos pacientes. Ajuda na recordação de experiências anteriores, memórias e imagens, bem como estimula as funções cognitivas (GUETIN, 2009).

Os resultados de nossa pesquisa, portanto, corroboram, de alguma maneira, com aqueles encontrados na prática clínica de cuidados paliativos, onde a Musicoterapia, em geral, visa a melhoria ou manutenção da qualidade de vida de pacientes, incluindo o gerenciamento do estresse e a regulação das emoções negativas, como por exemplo, ansiedade e depressão. 


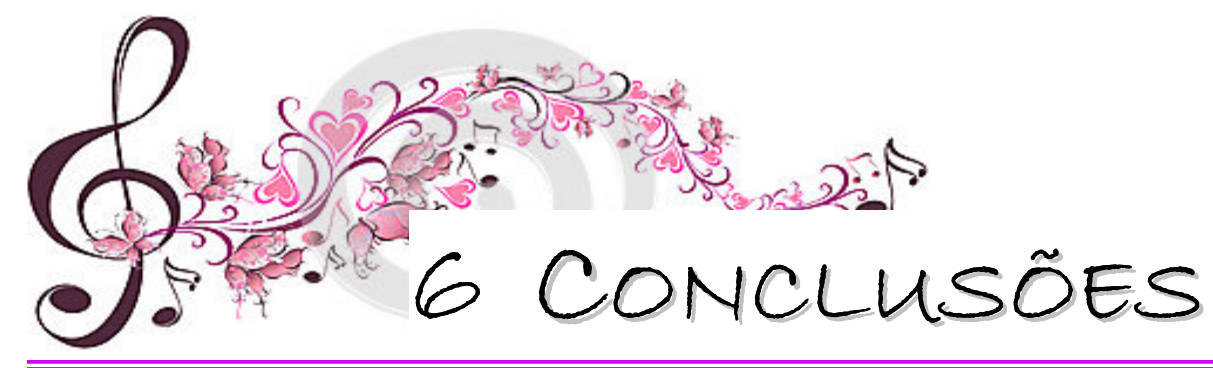


Em um contexto geral, conclui-se que a terapia pela Música com base na Sonata de Mozart para dois pianos interferiu, de uma forma positiva, nas respostas comportamentais de ratos avaliados em diferentes fases de desenvolvimento, considerando os seguintes resultados:

* Ratos machos apresentaram resposta ansiogênica com 1 mês de idade sem nenhuma outra observação relevante vista nas demais idades, enquanto que as fêmeas apresentaram resposta ansiolítica com 1, 2 e 3 meses. Estes resultados sugerem uma diferença dependente da idade.

* Esses resultados prévios parecem ser específicos e não dependentes da locomoção, visto que este parâmetro não foi afetado, na maioria das vezes, no teste do Campo aberto e nem na frequência de entradas nos braços fechados do LCE, quando a avaliação foi feita por pares de idade .

- No Teste do Nado forçado observou-se que somente animais com 1 mês de idade apresentaram diferença estatística de maneira contraditória, visto que os ratos machos reduziram o tempo de imobilidade decorrente provavelmente de um maior nível de estresse, enquanto que os ratos femeas apresentaram maior tempo de imobilidade sugerindo comportamento de apatia, compatível com o quadro de depressão. Não se descarta que esses resultados podem ter sido influenciados, até certo ponto, pelo desamparo materno, em decorrência do desmame ter ocorrido poucos dias antes dos procedimentos experimentais.

* No teste de Esquiva inibitória do tipo Step Down os dados mais significantes e homogêneos ocorreram com ratos de 1 e 2 meses de idade, de ambos os sexos. Esses resultados, entretanto, não pareceram ter sido influenciados pela música, provavelmente em decorrência do desenho experimental, visto que os mesmos procedimentos realizados com animais de 1 mês foram repetidos com as demais idades, criando uma espécie de memória adaptativa pelas sucessivas repetições. 


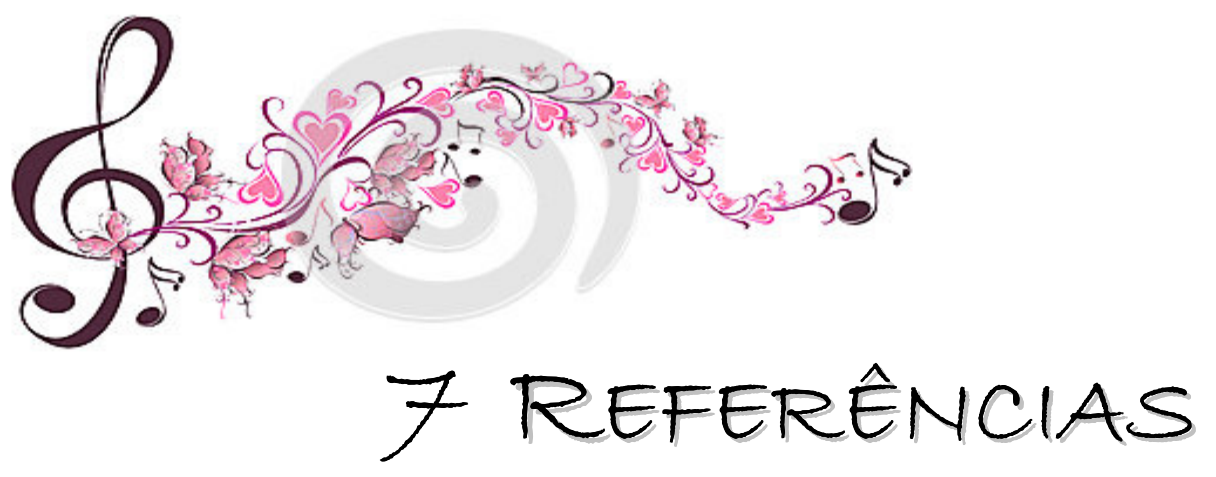


Angelucci F, Ricci E, Padua L, Sabino A, Tonali PA. Music exposure differentially alters the levels of brain-derived neurotrophic factor and nerve growth factor in the mouse hypothalamus. Neuroscience Letters. 429:152-155; 2007.

Archie P, Bruera E, Cohen L. Music-based interventions in palliative cancer care: a review of quantitative studies and neurobiological literature. Support Care Cancer. 21: 2609-2624; 2013.

Bear MF, Connors BW, Paradiso MA. Neurociências: desvendando o sistema nervoso. 2 ed. Porto Alegre: Artmed, 2002, pp.775-807.

Beck AT, Rush AJ, Shaw BF, Emery G. Terapia cognitiva da depressão. 1a edição. Porto Alegre: Artes Médicas; 1997.

Benenzon R. Teoria da musicoterapia: contribuição ao conhecimento do contexto não verbal. São Paulo: Summus Editorial; 1988.

Bhatia SK, Bhatia SC. Chilhood and adolescent depression. American Family Physician, 75: 73-80, 2007.

Blanchard DC, Blanchard RJ, Carobrez AP, Veniegas R, Rodgers RJ, Shepherd JK. MK-801 produces a reduction in anxiety-related antipredator defensiveness in male and female rats and a gender-dependent increase in locomotor behavior. Psychopharmacology. 108: 352-362, 1992.

Bouwknecht JA. Behavioral studies on anxiety and depression in a drug discovery environment: keys to a successful future. European Journal of Pharmacology. 753: 158-76, 2015.

Breitkopf SD, Leipzig. Sonate fur zwei pianoforte von W.A. Mozart. Koch. Verz. № 448. Ausgegeben; 1878.

Cammarota M, Barros DM, Vianna MRM, Bevilaqua LRM, Coitinho A, Szapiro G, Izquierdo LA, Medina JH, Izquierdo I. The transition from memory retrieval to extinction. Anais da Academia Brasileira de Ciências. 76: 573-582, 2004.

Cammarota M, Bevilaqua LR, Rossato Jl, Lima RH, Medina JH, Izquierdo I. Parallel memory processing by the CA1 region of the dorsal hippocampus and the basolateral amygdala. Proceedings of the National Academy of the Sciences of the United States of America. 105: 10279-1084, 2008.

Campbell DG. O efeito Mozart: explorando o poder da música para curar o corpo, fortalecer a mente e liberar a criatividade. Rio de Janeiro. Rocco; 2001.

Carr C, Odell-Miller H, Priebe S. A systematic review of music therapy practice and outcomes with acute adult psychiatric in-patients. Plos One. e70252; 2013. 
Choi AN, Lee MS, Cheong KJ, Lee JS. Effects of group music intervention on depression, anxiety, and relationships in psychiatric patients: a pilot study. Journal of Alternative and Complementary Medicine. 14: 567-570; 2008.

Cipriani A, Smith K, Burgess S, Carney S, Goodwin G, Geddes J. Lithium versus antidepressants in the long-term treatment of unipolar affective disorder. The Cochrane Database of Systematic Reviews, 18;(4):CD003492, 2006.

Dantzer R, Bluthé RM, Koob GF, Le Moal M. Modulation of social memory in male rats by neurohypophyseal peptides. Psychopharmacology 91: 363-368, 1987.

Delgado MR, Olsson A, Phelps EA. Extending animal models of fear conditioning to humans. Biological Psychology. 73: 39-48, 2006.

Ehret AM, Kowalsky J, Rief W, Hiller W, Berking M. Reducing symptoms of major depressive disorder through a systematic training of general emotion regulation skills: protocol of a randomized controlled trial. BioMed Central Psychiatry. 14: 1-9; 2014.

Eisendrath SJ, Gillung EP, Delucchi KL, Chartier M, Mathalon DH, Sullivan JC, Segal ZV, Feldman MD. Mindfulness-based cognitive therapy (MBCT) versus the health-enhancement program (HEP) for adults with treatment-resistant depression: randomized control trial study protocol. BioMed Central Complementary \& Alternative Medicine. 14: 1-11; 2014.

EIBatsh MM. Antidepressant-like effect of simvastatin in diabetic rats. Canadian Journal of Physiolofy and Pharmacology. 24:1-8, 2015.

Elliott R, Zahn R, Deakin JFW, Anderson LM. Affective cognition and its disruption in mood disorders. Neuropsychopharmacology Reviews. 36: 153-182; 2011.

Emptage NJ, Carew TJ. Long-term synaptic facilitation in the absence of shortterm facilitation in Aplysia neurons. Science 262: 253-256, 1993.

Erkkilä J, Gold C, Fachner J, Ala-Ruona E,Punkanen M,Vanhala M. The effect of improvisational music therapy on the treatment of depression: protocol for a randomised controlled trial. Biomed Central Psychiatry. 8: 1-9, 2008.

Fukui H., Arai A, Toyoshima K. Efficacy of music therapy in treatment for the patients with Alzheimer's disease. International Journal of Alzheimer's Disease. 2012: 1-6; 2012.

García-Cárdenas N, Olvera-Hernández S, Gómez-Quintanar BN, FernándezGuasti A. Male rats with same sex preference show high experimental anxiety and lack of anxiogenic-like effect of fluoxetine in the plus maze test. Pharmacology Biochemitry and Behavior. 135: 128-135, 2015. 
Gold C, Solii HP, Kruger V, Lie SA. Dose-response relationship in music therapy for people with serious mental disorders: systematic review and meta-analysis. Clinical Psychology Review. 29: 193-207; 2009.

Gold PE, Van Buskirk RB, Mcgaugh JL. Effects of hormones on time-dependent memory storage processes. Progress in Brain Research. 42: 210-211, 1975.

Gold PW. The organization of the stress system and its dysregulation in depressive illness. Molecular Psychiatry. 20(1): 32-47, 2015.

Goldman-Rakic PS. Working memory and the mind. Scientific American. 267: 110117, 1992.

Graeff FG. Medicamentos ansiolíticos. In: Fundamentos de Psicofarmacologia, Editores: Graeff FG, Guimarães FS. Ed. Atheneu, São Paulo, p 123-160, 1999.

Gray J. Drug effects on fear and frustration. Possible limbic site of action of minor tranquilizers, in Handbook of Psychopharmacology: Drugs, Neurotransmitters and Behavior (Iversen, L.L.; Iversen, S.D. and Snyder, S.H., eds), Plenum, New York, vol. 8, pp. 433-529, 1977.

Guetin S, Portet F, Picot MC, Defez C, Pose C, Blayac JP. Impact of music therapy on anxiety and depressionfor patients with Alzheimer's disease and on theburden felt by the main caregiver (feasibility study). L Encephale. 35: 57- 65; 2009.

Handley SL, Mithani S. Effects of alpha-adrenoreceptor agonists in a mazeexploration model of "fear"-motivated behaviour. Naunyn-Schmiedeberg's Archives of Pharmacology. 327: 1-5; 1984.

Hegde S. Music-based cognitive remediation therapy for patients with traumatic brain injury. Frontiers in Neurology. 5: 1-7; 2014.

Higa-McMillan CK, Francis SE, Rith-Najarian L, Chorpita BF. Evidence Base Update: 50 Years of Research on Treatment for Child and Adolescent Anxiety. Journal of Clinical Child and Adolescent Psychology, 18: 1-23, 2015.

Imhof J.T., Coelho Z.M.I., Schmitt M.L. Morato G.S., Carobrez A.P. Influence of gender and age on performance of rats in the elevated plus maze apparatus. Behavioural Brain Research. 56: 177-180; 1993.

Izquierdo I, Medina JH, Vianna MR, Izquierdo LA, Barros DM. Separate mechanisms for short- and long-term memory. Behavioural Brain Research. 103: $1-11,1999$.

Kamioka $H$, Tsutani K, Yamada M, Park H, Okuizumi $H$, Tsuruoka $K$ et al. Effectiveness of music therapy: a summary of systematic reviews based on 
randomized controlled trials of music interventions. Dove Press Journal. 8: 727 $754 ; 2014$.

Kandel ER, Scwartz JH, Jesse TM. Principles of neural science. 4 ed. New York: Elsevier, 2000.

Kim DS, Park YG, Choi JH, Im SH, Jung KJ, Cha YA, Jung CO, Yonn, YH. Effects of Music Therapy on mood in stroke patients. Yonsei Medical Journal. 52: 977$981 ; 2011$.

KrumhansI CL. An exploratory study of musical emotions and psychophysiology. Canadian Journal of Experimental Psychology. 51: 336-353; 1997.

Li CH, Liu CK, Yang YH, Chou MC, Chen CH, Lai CL. Adjunct effect of music therapy on cognition in Alzheimer's disease in Taiwan: a pilot study. Dove Press Journal. II: 291- 296; 2015.

Lin L, Lee M, Wei R, Mok H, Yang R. Mozart K.448 listening decreased seizure recurrence and epileptiform discharges in children with first unprovoked seizures: a randomized controlled study. BioMed Central Complementary \& Alternative Medicine. 14: 1-8; 2014.

Liu A, Jain N, Vyas A, Lim LW. Ventromedial prefrontal cortex stimulation enhances memory and hippocampal neurogenesis in the middle-aged rats. eLife. 4: $1-21 ; 2015$.

Lucena GM, Porto FA, Campos EG, Azevedo MS, Cechinel-Filho V, Prediger RD, Ferreira VM. Cipura paludosa attenuates long-term behavioral deficits in rats exposed to methylmercury during early development. Ecotoxicol Environ Saf. 73(6): 1150-8, 2010

Lucena GM, Prediger RD, Silva MV, Santos SN, Silva JFB, Santos AR, Azevedo MS, Ferreira VM. Ethanolic extract from bulbs of Cipura paludosa reduced longlasting learning and memory deficits induced by prenatal methylmercury exposure in rats. Developmental Cognitive Neuroscience. 3:1-10; 2013.

Lynn DA, Brown GR. The Ontogeny of anxiety-Like behavior in rats from adolescence to adulthood. Developmental Psychobiology. 8: 731-739; 2010.

Maia CS, Lucena GM, Corrêa PB, Serra RB, Matos RW, Menezes FC, Santos SN, Sousa JB, Costa ET, Ferreira VM. Interference of ethanol and methylmercury in the developing central nervous system. Neurotoxicology. 30(1): 23-30, 2009.

Masataka M, Perlovsky L. The efficacy of musical emotions provoked by Mozart's music for the reconciliation of cognitive dissonance. Scientific Reports. E2694; 2012. 
Matthews BR. Memory dysfunction. Behavioral Neurology and Neuropsychiatry: 613-26, 2015.

McBride WJ; Li TK. Animal models of alcoholism: neurobiology of high alcoholdrinking behavior in rodents. Critical. Reviews in Neurobiology, 12: 339-369, 1998.

McDermott O, Orrell M, Ridder HM. The importance of music for people with dementia: the perspectives of people with dementia, family carers, staff and music therapists. Aging \& Mental Health. 18: 706-716; 2014.

Mcgaugh JL. Time-dependent processes in memory storage. Science 153: 13511358, 1966.

Medeiros GF, Pereira E, Granzotto N, Ramos A. Low-anxiety rat phenotypes can be further reduced through genetic intervention. Plos One. 8:e83666; 2013.

Montgomery KC. The relation between fear induced by novel stimulation and exploratory behaviour. Journal of Comparative and Physiological Psychology. 48: 254-260, 1955.

Mowla A, Mosavinasalo M, Pani A. Does fluoxetine have any effect on the cognition of patients with mild cognitive impairment? A double-blind placebocontrolled clinical trail. Journal of Clinical Psychopharmacology, 27: 67-70, 2007.

Oliveira CL, Lima TCM, Carobrez AP. Structure of the rat behaviour in the forced swimming test. Behavioural Brain Research. 158:243-250; 2005.

Park J-S, Park S, Cheon C-H, Jang B-H, Lee S-H, Lee S-H, Chung S-Y, Kim J-W, Jeon $\mathrm{C}-\mathrm{Y}$, Park J-H, Shin Y-C, Ko S-G. Effect of oriental medicine music therapy on patients with Hwa-byung: a study protocol for a randomized controlled trial. Trials. 13: 1-7; 2012.

Pellow S, Chopin P, File SE, Briley M. Validation of open: closed arm entries in an elevated plus-maze as a measure of anxiety in the rat. Journal of Neuroscience Methods.14: 149-167; 1985.

Porsolt RD, Bertin A, Jalfre M. Behavioural despair in mice: a primary screening test for antidepressants. Archives Internationales de Pharmacodynamie. 229: 327336; 1977.

Prediger RDS, Takahashi RN. Modulation of short-term memory in rats by adenosine A1 and A2 receptors. Neurocience Letter. 376: 160-165, 2005.

Quinn R. Comparing rat's to human's age: How old is my rat in people years? Nutrition, 21: 775-777, 2005. 
Raglio A, Attardo L, Gontero G., Rollino S., Groppo E., Granieri E. Effects of music and music therapy on mood in neurological patients. World Journal Psychiatry. 5: 68-78; 2015.

Ratcliff CG, Prinsloo S, Richardson M, Baynham FL, Lee R, Chaoul A, Marlene Z. Cohen MZ, Lima M, Cohen L. Music therapy for patients who have undergone hematopoietic stem cell transplant. Evidence-Based Complementary and Alternative Medicine. 2014:1-9, 2014.

Sadock BJ, Sadock VA. Compêndio de psiquiatria - Ciência do comportamento e psiquiatria clínica. 9ª edição. Porto Alegre: Artes Médicas; 2007.

Sakamoto M, Ando H, Tsutou A. Comparing the effects of different individualized music interventions for elderly individuals with severe dementia. International Psychogeriatrics. 25: 775-784; 2013.

Satoh M, Ogawa J-I, Tokita T, Nakaguchi N, Nakao K, Kida H. The effects of physical exercise with music on cognitive function of elderly people: Mihama-kiho project. Plos One. 9: e95230; 2014.

Schmauss C. An HDAC-dependent epigenetic mechanism that enhances the efficacy of the antidepressant drug fluoxetine. Scientific Reports. 5: 1-8, 2015.

Singh AB, Bousman CA, Ng CH, Byron K, Berk M. Effects of Persisting Emotional Impact from Child Abuse and NorepinephrineTransporter Genetic Variation on Antidepressant Efficacy in Major Depression: A Pilot Study. Clinical Psychopharmacology and Neuroscience. 13: 53-61, 2015.

Slavich, GM e Irwin MR. From stress to inflammation and major depressive disorder: a social signal transduction theory of depression. Psychological Bulletin.140:774-815; 2014.

Susswein AJ, Katzoff A, Miller N, Hurwitz I. Nitric oxide and memory. Neuroscientist. 10: 153-162, 2004.

Tasset I, Quero I, García-Mayórgaz AD, Del Río MC, Túnez I, Montilla P. Changes caused by haloperidol are blocked by music in Wistar rat. Journal of Physiology and Biochemistry. 68:175-179; 2012.

Thoma MV, La Marca R, Brönnimann R, Finkel L, Ehlert U, Nater UM. The effect of music on the human stress response. Plos one. 8: 1-12; 2013.

Trainor L. Science \& music: the neural roots of music. Nature, 29;453:598-599, 2008. 
Warth M, Kessler J, Koenig J, Alexander F Wormit AF, Hillecke TK, Hubert J Bardenheuer HJ. Music therapy to promote psychological and physiological relaxation in palliative care patients: protocol of a randomized controlled trial. BioMed Central Palliative Care, 13: 1-7; 2014.

Wecker L, Catalano G. Tratamento da ansiedade e dos distúrios do sono. In: Brody Farmacologia Humana. Ed: Minneman KP, Wecker L., Editora Mosby Elsevier, 4⿳ạ. Edição, pág. 285-286, 2006.

Yang E-J, Lin EW, Hensch TK. Critical period for acoustic preference in mice. PNAS.109:17213-17220; 2012. 


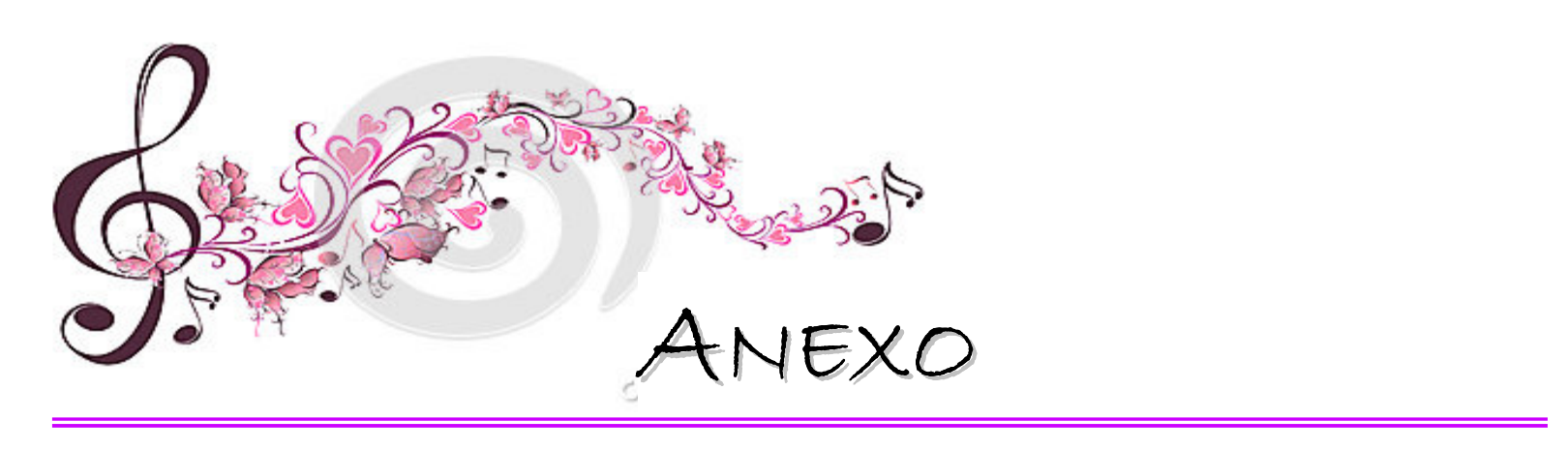


Universidade de Brasília Instituto de Cièncias Biológicas
Comité de Ettica no Uso Animal

Brasilia, 08 de novembro de 2013.

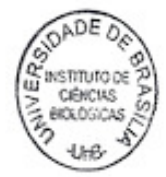

\section{DECLARAÇÃO}

Declaramos que o projeto intitulado "INFLUÊNCIA DA MUSICOTERAPIA NO SISTEMA NERVOSO EM DESENVOLVIMENTO: UMA AVALIAÇÃo EXPERIMENTAL", UnBDOC n. ${ }^{9} 80243 / 2013$, sob responsabilidade da Professora Vânia Moraes Ferreira foi avaliado e aprovado pela Comissão de Ética no Uso Animal (CEUA) do Instituto de Ciências Biológicas da Universidade de Brasilia.
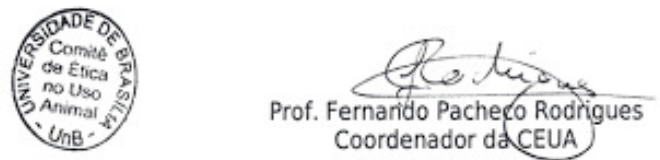

- Este documento se restringe dे avalią̧̊o ética do projeto suprackado e năo subssitui outras licenças e permissbes que porventura se façam necessarias. 